\title{
Foreign Aid and the Business Cycle
}

\author{
Stéphane Pallage \\ Michel A. Robe*
}

January 2000

\begin{abstract}
In this paper, we document empirical regularities in the foreign aid flows to developing countries over the last three decades. In spite of a large body of literature on foreign aid and its impact on recipients, surprisingly little is known about its business cycle characteristics. We show that for the vast majority of African recipients, aid flows are a major source of income that is highly volatile and, most importantly, overwhelmingly procyclical. For recipients outside of Africa, we find a similar - if somewhat less pronounced - pattern of aid procyclicality. In contrast, there is little evidence of aid procyclicality with the business cycle of donors. In light of the very high volatility of output in developing countries, the procyclicality of foreign aid flows from the recipients' perspective raises serious questions related to their welfare and growth.
\end{abstract}

Key words: Foreign aid, business cycles, volatility, empirical regularities.

JEL classification: E32, F35.

\footnotetext{
*We thank Ricardo Cavalcanti, John Devereux, Finn Kydland and Christian Zimmermann for very insightful comments. Many thanks also to Sebnem Akkaya, Steve Ambler, Arne Bigsten, Tim Burch, Sonia DiGiannatale, David Dollar, Bill Easterly, Vihang Errunza, Tarhan Feyzioğlu, Pat Fishe, Rick Green, Alain Guay, Huw Lloyd-Ellis, Angelo Melino, David Reeb, İnci Robe, Tuğrul Temel, Cheng Wang, and to seminar participants at the University of Miami, UQAM, the University of Toronto, the World Bank, the International Monetary Fund, Göteborg University and the T2M meetings in Montreal for useful suggestions. Pallage: CREFE and Department of Economics, University of Quebec at Montreal, C.P. 8888 Succursale Centre-Ville, Montreal, QC, H3C 3P8. Tel: 514-987-3000 (ext.8370). Email: pallage.stephane@uqam.ca. Robe: Kogod School of Business, American University, 4400 Massachusetts Avenue NW, Washington, DC 20015. Tel: 202-885-1880. Email: mrobe@american.edu.
} 


\section{Introduction}

In this paper, we document some key business cycle properties of foreign aid flows to developing countries. We identify two striking empirical regularities. First, aid flows are highly volatile over time - on average, two to three times as volatile as the recipient's output. Second, for most African countries, net aid inflows are strongly positively correlated with their domestic output. Outside of Africa, we find a similar, if somewhat less pronounced, pattern of aid procyclicality.

To understand why these empirical regularities are important, recall that output fluctuations in developing countries are much stronger than in industrialized economies. Indeed, we document that the gross domestic product of an aid recipient is several times as volatile as that of a donor. For developing countries, though, customary ways to smooth out the impact of output fluctuations on domestic consumption are likely to be very onerous. For instance, it has been argued that, because of moral hazard and repudiation risk, heavily indebted nations are often denied new loans (or are asked to repay old ones) precisely when their economies suffer adverse shocks - see, e.g., Atkeson (1991). At the same time, foreign aid is a major source of income to recipients, especially in Africa, where it averages $12.5 \%$ of gross domestic product and constitutes by far the main source of foreign capital. In such an environment, foreign aid has the potential to play a key role in smoothing out developing countries' output fluctuations. Our results imply that, all in all, aid flows do not play that role.

Admittedly, it might be argued that, except for emergency relief, the chief purpose of aid is not to act as an insurance device but, instead, to fuel economic development, in which case it is not clear a priori whether one should expect aid flows to be procyclical or countercyclical. It is well established, however, that output fluctuations affect growth negatively - see, e.g., Hamilton (1989) and Ramey \& Ramey (1995). Hence, even if aid were meant solely to help foster growth, serious concerns would nonetheless arise from the fact that aid disbursement patterns contribute to the volatility of developing countries' disposable income.

Our findings are robust. Our data set comprises various yearly aid and output series for sixty-three recipient and eighteen donor countries between 1969 and 1995. We find few differences between the cyclical behavior of multilateral as opposed to bilateral aid disbursements, even though multilateral aid flows are relatively more volatile than their bilateral counterparts. Likewise, aid commitments fluctuate more than actual net disbursements, but both commitments and disbursements are procyclical. We also pay special attention to Africa, because it is the region where aid is largest relative to recipient GDP and aid procyclicality is most striking. Regardless of the measure used for domestic output, net aid receipts are procyclical for at least two-thirds of the thirty-eight countries in our African subsample and are countercyclical for, at most, a few of them. Key components of African aid flows, such as grants or technical assistance, are as strongly 
procyclical as total aid flows. Finally, we find no evidence that the procyclicality of aid is a function of an African recipient's former colonial power, its choice of exchange rate regime or some other criterion.

We complete the paper by analyzing the cyclical properties of aid flows from donors' perspective. Even though overall aid disbursements are positively correlated with donor output, aid disbursements to the recipient countries in our sample are not. A corollary is that the procyclicality of aid inflows experienced by those aid recipients is not the mere result of the conjunction of (i) positive comovements between North-South business cycles [Kouparitsas (1998); Agénor, McDermott, \& Prasad (1999)] and (ii) a positive correlation between donors' aid policies and their business cycles.

Despite a large body of literature on foreign aid, surprisingly little is known about the business cycle properties of aid flows. Our contribution is to identify a series of key empirical regularities pertaining to aid and the business cycle. The philosophy of the present paper, in that sense, is similar to that of Kydland \& Prescott (1990). ${ }^{1}$ Clearly, we expose ourselves to the criticism that we do "measurement without explicit theory." Given the sheer magnitude of aid flows for the recipients, and the likely significant welfare and growth consequences of aid disbursement patterns, we think that the facts we report are important in their own right and should therefore guide the construction of theoretical models of foreign aid.

Much of the literature on foreign aid has focused on how aid levels affect the growth of recipient countries. On the one hand, Boone $(1994,1996)$ shows that, within a growth model of a recipient country, aid is fully consumed. He then argues that the model's prediction is verified empirically for a large set of countries over a ten-year period. Easterly (1999) makes a similar point. On the other hand, several recent papers find that aid has a positive effect on growth, although they suggest that the relationship between aid and growth may depend on the recipient's having adopted sound economic policies [Burnside \& Dollar (1997)] or, independent of the policy mix, is significant but non-linear [Hansen \& Tarp (2000)]. In contrast to all these studies, Lensink \& Morrissey (1999) analyze the impact of aid uncertainty on growth. Their results suggest that the effect of aid on growth is a function, not only of aid levels, but also of the stability of aid flows.

Our paper is also connected to the literature that derives optimal patterns of capital flows to developing countries. Most of that literature models commercial loans to sovereign borrowers [e.g., Atkeson (1991) and Marcet \& Marimon (1992)]. More closely related to the present paper is Svensson (1995), who characterizes optimal aid disbursement policies within a two-date agency model of the relationship between an altruistic donor and a pair of recipients. Svensson (1995) shows that, in a first-best environment in which policies

\footnotetext{
${ }^{1}$ Other papers documenting business cycle facts include Cooley \& Ohanian (1991) Backus \& Kehoe (1992), Fiorito \& Kollintzas (1994), Chadha \& Prasad (1994) or, more recently, Ambler, Cardia, \& Zimmermann (1999).
} 
could be fully contracted on, aid receipts would be countercyclical. However, because of its limited ability to monitor the recipient's use of aid, the donor can at best achieve a second-best outcome in which aid is tied to the recipient's economic performance. As a result, aid receipts increase when a good output realization occurs. In that sense, second-best aid receipts may be procyclical.

Finally, our paper is at the intersection of two recent strands of literature. The first studies various business cycle phenomena in developing countries - see, in particular, Mendoza (1992, 1995), Carmichael, Samson, \& Keita (1999), Talvi \& Végh (1998) and Agénor et al. (1999). The second studies the business cycle properties of international capital flows - see, e.g., Lane (1999). In contrast to all these papers, we focus on the empirical regularities of foreign aid to developing countries.

The paper is organized as follows. In Section 2, we describe our data and discuss measurement issues. In Section 3, we document empirical regularities of aid flows from both recipients' and donors' perspectives. In Section 4, we discuss our findings and conclude.

\section{Measurement and data}

We analyze the business cycle properties of foreign aid flows received by developing countries between 1969 and 1995. A recipient country is excluded from our sample if: (i) it had not achieved independence by the end of 1975; (ii) fewer than twenty consecutive years of data are available for that country; or (iii) the country was a net donor of aid in some years (e.g., Libya). For the remaining countries, we only consider the largest block of contiguous data-years during which the country was independent. Our sample of recipients comprises sixty-three countries, thirty-eight of which are located in Africa. When we analyze the cyclical behavior of aid from the donor's perspective, we focus on members of the Organization for Economic Cooperation and Development [OECD] that belong to its Development Assistance Committee [DAC]. Of the twenty-one current DAC member countries, we eliminate three due to lack of sufficient aid data. For the remaining eighteen, we again only consider the largest block of contiguous data-years.

\subsection{Aid flows}

The conventional measure of foreign aid is the Official Development Assistance [ODA] numbers published by the OECD. This measure encompasses grants, the value of technical assistance, and concessional loans. We employ data for net ODA disbursements and for ODA commitments ("firm obligations to disburse that are supported by the availability of public funds").

Because loans are classified by the OECD as concessional when they have at least a $25 \%$ grant component, 
using net ODA disbursements to measure aid may overstate the actual amount donated. The overstatement should be small in our African subsample since the median grant element, reported by the OECD, exceeds 90\%. ${ }^{2}$ Still, Chang, Fernandez-Arias, \& Serven (1998) argue that the OECD figures overstate the grant element of ODA loans. We therefore verified the robustness of our results to the exclusion of ODA loans, by analyzing the cyclical behavior of grants only. ${ }^{3}$

There is no a priori reason why the aid policy of individual donors should be similar to that of international organizations such as the World Bank. In order to capture possible differences, we therefore decompose ODA into multilateral [Mult] and bilateral [Bilat] aid. The first component measures aid given by international organizations, while the second component encompasses all government-to-government aid distributed by DAC member countries. ${ }^{4}$

All aid series consist of annual data and are expressed in current US\$. We transform them in per capita real terms using methods explained below.

\subsection{Real output and aid}

Each dollar of resources available to a recipient country can be spent on foreign or domestic goods and services. Because of differences in purchasing power, the real value of an aid dollar differs whether it be spent abroad or locally.

In light of evidence that foreign exchange constraints are important in limiting the quantity of goods a developing country can import [Stryker \& Tuluy (1989)], ${ }^{5}$ we use actual dollar figures for both output and aid. This approach helps us capture the ability of a country to import and the role of aid in lessening foreign exchange constraints. We employ, as measure of recipient output, the official per capita Gross Domestic Product [GDP] at market prices in current US\$ recorded in the World Bank's World Development Indicators [WDI] (1998). Consistently, we deflate GDP and aid series using each country's implicit import deflator $(1990=100)$, which we compute from the WDI. This deflator captures the changes in the price of

\footnotetext{
${ }^{2} \mathrm{OECD}$ data on the grant component of concessional loans to individual recipients is available from 1983 onward.

${ }^{3}$ We also verified the robustness of our results to an alternative measure of aid: the country's net receipts of Official Transfers [OT] reported until 1992 in the World Bank's World Tables (1994). This second measure combines grants, the value of technical assistance, and food aid, but not concessional loans. We obtained very comparable results.

${ }^{4}$ Our measure of bilateral aid therefore excludes bilateral aid from Arab sources. In general, the exclusion should matter little in our sample. Admittedly, there are six countries for which Arab aid is of importance: Jordan (67.8\%), Mauritania (34.2\%), Morocco (25\%), Somalia (10.8\%), Sudan (22\%) and Tunisia (12.8\%). Across all countries in our sample and all years, however, the median ratio of Arab bilateral ODA to bilateral receipts from all sources is a mere $0.01 \%$.

${ }^{5}$ See also Krueger, Michalopoulos, \& Ruttan (1989) for a review of that literature.
} 
the country's typical basket of imports. ${ }^{6}$

It can be argued that this first approach is inappropriate if the country's available resources are used principally for domestic purchases. In that case, output and aid may be better expressed in US dollars adjusted for differences in purchasing power parities. In a sensitivity analysis, we took that perspective: we measured output as Real Gross Domestic Product per capita, from the Summers \& Heston (1991) Penn World Tables (Mark 5.6), and adjusted aid dollar series consistently. Results were not qualitatively affected by that second measurement approach.

To assess the business cycle properties of aid from a donor's perspective, the appropriate numeraire is that donor's local currency. Gross domestic product figures for our eighteen donors come from the OECD Statistical Compendium (1998). Aid series are converted into local currency using the current dollar exchange rate from the Statistical Compendium. Both aid and output series are expressed in per capita terms and deflated using the local GDP deflator (OECD, 1990=100).

\subsection{Business cycles}

Following Lucas (1977) and Kydland \& Prescott (1990), we define business cycles as the deviations of output from trend, and business cycle facts as the statistical properties of the comovements of output deviations from trend with deviations from trend of other aggregate time series. When examining the business cycle aspects of foreign aid, we first detrend each data series using the Hodrick \& Prescott (1980) [HP] filter. For any series $x$, the HP filter extracts the growth component $x^{g}$ and the cyclical component $x^{c}=x-x^{g}$ by minimizing the following loss function:

$$
\sum_{t} x_{t}^{c^{2}}+\lambda \sum_{t}\left(\left(x_{t+1}^{g}-x_{t}^{g}\right)-\left(x_{t}^{g}-x_{t-1}^{g}\right)\right)^{2}
$$

where $\lambda$ is a weight that reflects the relative variance of the two components. We adopt the value of $\lambda=100$, which is conventional for yearly data. ${ }^{7}$ We work throughout with the logarithms of the series, because we are mainly interested in percentage deviations from trend. In line with Baxter \& King (1995), we ensure that our results are not affected by abnormal behavior at the end points of the series, by dropping the first and last two detrended observations before computing moments of the cyclical components of each series.

\footnotetext{
${ }^{6}$ For the few countries whose GDP data were not available in the WDI, figures from the World Bank World Tables (1995) were used instead. Likewise, when the implicit import deflator could not be calculated, we employed instead the Import Price Index computed by the United Nations Conference on Trade and Development [UNCTAD] and reported in the World Bank World Tables (1995).

${ }^{7}$ See, e.g., Backus \& Kehoe (1992). Our results are robust to using $\lambda=10$, a value which is also acceptable.
} 
To assess the business cycle properties of foreign aid, we compute the correlations between the cyclical components of aid and output, contemporaneously and with the series shifted backward or forward up to two years. As is customary [Kydland \& Prescott (1982), Cooley \& Prescott (1995)], a positive contemporaneous correlation means that aid receipts are procyclical, whereas a negative contemporaneous correlation implies that aid flows are countercyclical. In case of procyclicality, we identify possible phase shifts (leads and lags) by how early or how late with respect to the contemporaneous period the highest correlation appears.

\section{Empirical regularities}

Over the period 1969-1995, we identify the following empirical regularities:

1. Foreign aid is a major source of income for recipients. In Africa, the average fraction of net ODA receipts to GDP is $12.5 \%$, the median is $10.3 \%$ (see Table 1, Panel I). For some of the poorest countries, ODA inflows even exceed one third of GDP over the sample period: Somalia (34.2\%), Guinea Bissau $(44.2 \%)$ and Cape Verde $(47.2 \%)^{8}$

The relative importance of aid makes Africa special. For developing countries outside of Africa, aid, while still important, is not as large relative to domestic output. Net ODA receipts average $4 \%$ of their GDP, with a median ratio of $2 \%$ (Table 1 , Panel II).

- From those aid flows, the largest share is made through bilateral channels. In Africa, bilateral aid receipts are on average $70 \%$ higher than multilateral ones; for recipients outside of Africa, bilateral aid is almost twice as large as multilateral aid (Table 1).

- Commitments of all sources are typically larger than disbursements. Over the sample period, African recipients are on average promised aid flows 2\% of GDP more than what they receive (Table 1). Outside of Africa, firm promises to disburse average 1\% of GDP more than actual disbursements. Although one could think that some promises never materialize, the explanation is likely simpler: disbursements are net of possible principal repayments, whereas commitments are not.

2. Recipients' output is much more volatile than industrialized countries' output. The first column of Table 2 displays the volatility of the cyclical component of output in recipient countries. We compute

\footnotetext{
${ }^{8}$ For, African countries, furthermore, foreign aid is by far the largest source of foreign capital. We computed that, between 1975 and 1995, across all African recipients in our sample, net ODA receipts averaged more than $92 \%$ of all net capital inflows, private and public, reported by the OECD.
} 
the volatility of each series as the standard deviation of its cyclical component. This measure is appealing because it is expressed in percentage terms and is directly comparable across series.

For African countries in our sample, the volatility of GDP averages $13.2 \%$ over the period 196995. For the remaining developing countries in our sample, the figure is $12.9 \%$. Those figures are consistent with the volatility figures documented by Mendoza (1995) and Carmichael et al. (1999) for, respectively, 23 and 19 developing or recently industrialized countries using yearly data, and by Agénor et al. (1999) for 12 middle income countries using quarterly data.

The magnitude of output fluctuations in donor countries (Table 3), by comparison, is a lot smaller, with an average volatility of $2.19 \%$ over the same period (2.18\% in the United States). In other words, shocks to poor countries are about six times more severe than shocks to industrialized countries. ${ }^{9}$

3. Aid flows are even more volatile. The volatility of net ODA receipts averages approximatively twice that of recipient GDP, both in Africa and outside of Africa (Table 2, second column). ${ }^{10}$ Multilateral aid flows are more volatile than bilateral ones, and commitments from all sources are more volatile than receipts.

4. In Africa, aid inflows are overwhelmingly procyclical. For more than two-thirds (26) of the African recipients in our sample, the cyclical component of ODA receipts is strongly positively correlated with the cyclical component of domestic output. Only 2 African countries in 38 (5\%) experience countercyclical net ODA receipts. Table 4 summarizes the cyclical properties of foreign aid from recipients' perspective, which are then detailed in Table 5. Figure 1 provides a snapshot of this result and shows that countries for which aid inflows are negatively correlated with output are the exception. Outside of Africa, aid procyclicality is somewhat less pronounced: 4 recipients in 25 (16\%) experience countercyclical aid flows, whereas for 12 others (48\%) net ODA receipts are procyclical. Aid is acyclical for the remaining 9 countries.

Over the entire sample, we find few differences between the cyclical properties of bilateral and multilateral aid receipts, the latter being procyclical for just 3 more countries than the former.

\footnotetext{
${ }^{9}$ This number only partly reflects the choice of a different deflator for both sets of countries. Indeed, when Summers \& Heston (1991) output figures and deflators are used for both donors and recipients alike, the volatility of output is still much stronger for recipients than for donors. For example, the median output volatility becomes $5.9 \%$ for African recipients, which is still more than 2.5 times the figure for the United States.

${ }^{10}$ Our measure of volatility (the percentage deviation from trend) is appropriate to assess the relative magnitude of fluctuations. Clearly, if one were to think in terms of absolute variations, one would need to correct that relative volatility by the share of net ODA receipts in GDP.
} 
- Commitments are not countercyclical. If there are delays before aid can be disbursed, the cyclical properties of aid commitments may differ from those of actual disbursements. As Table 4 and Figure 1 suggest, aid commitments are less clearly procyclical. There is hardly any evidence, however, of stronger countercyclicality.

- Leads and lags are a minor issue. For one fifth of the countries with procyclical aid flows, ODA receipts lag the cycle; leads are identified for just 4 countries and, for the remainder, the highest correlation of disbursements with GDP is the contemporaneous one. Bilateral and multilateral aid show a similar pattern. So do commitments.

- Grants are procyclical as well. For African recipients, we also analyzed the comovements of output and some of the components of ODA, such as grants and technical assistance [TA] (which on average accounts for $30 \%$ of grants). We do not report these correlations in the tables, because the results are strikingly similar: grants are procyclical for two-thirds of the recipients, while technical assistance is procyclical for $76 \%$ of African recipients.

- No subgroup of countries seems to stand out.

* Figure 2 plots, for each recipient, the contemporaneous correlation between the cyclical components of ODA and GDP against (i) the average level of per-capita output over the sample period, (ii) the volatility of output and (iii) a measure of aid dependency, the average ODA-GDP ratio. First, whether for African recipients, non-African recipients or overall, we find that the relationship between the correlation and average GDP is both weak and statistically insignificant. Next, the only statistically significant relationship between aid procyclicality and the volatility of GDP is for non-African recipients (higher levels of output volatility are associated with greater correlations). Finally, once we exclude the three countries for which aid amounts to more than $30 \%$ of GDP, we find no relationship between the procyclicality of aid inflows and the ODA-GDP ratio. ${ }^{11}$

* There appears to be no qualitative difference between former colonies of France or the United Kingdom with respect to the comovements of aid and output. Likewise, the twelve franc-CFA countries in our sample display no major difference from the rest.

- In Figures 3 A-C, we plot the data for a selection of countries. Burkina Faso and Madagascar, for example, are obvious cases of procyclical ODA disbursements (especially after 1976 for

\footnotetext{
${ }^{11}$ Naturally, if aid is sufficiently massive relative to GDP, it should be expected that increases in aid would raise output directly (through aggregate demand effects, or the relaxation of foreign exchange constraints for critical imports). Consistent with this conjecture, if we do not exclude the three African countries for which ODA receipts exceed 30\% of GDP, we find a weakly positive (but statistically significant) relationship between aid procyclicality and the ODA-GDP ratio.
} 
Burkina Faso). Botswana also exhibits positive comovements between ODA and GDP, although there appears to be a lead after 1978. In the case of Senegal, ODA lags the cycle by one year. In contrast, Mali is clearly a country with countercyclical aid. ODA disbursements and GDP in Niger and the Central African Republic are essentially uncorrelated, although in the case of the latter, one could possibly identify a period of procyclical ODA prior to 1983.

5. Results are robust. In addition to the above, we carried out a series of robustness checks for African countries, because the latter are the recipients for which aid procyclicality is most striking. Our results are robust to:

- an alternative measure of output. Instead of the World Bank GDP numbers, we employed real GDP figures from the Summers-Heston Penn World Tables, which are adjusted for purchasing power differences. As discussed in Section 2, we consistently adjusted the aid series and deflated all figures with the implicit GDP deflator from their dataset;

- two measures of aid that do not encompass concessional loans, for which the aid component may arguably be overstated. Instead of net ODA receipts, we took official transfers [OT] from the World Bank World Tables (1994); as mentioned above, we also simply used ODA grants reported by the OECD.

- an alternative deflator: instead of the import deflator computed from the World Bank WDI, we used the imports price index (IPI) from the UNCTAD.

In none of these sensitivity analyses were our results qualitatively altered.

6. Donors give on average less than 0.3\% of their own GDP. Over the 1969-1995 period, the most generous donor in our sample is the Netherlands, with an average ratio of ODA disbursements to GDP of $0.58 \%$ (Table 6). Aid to African recipients in our sample averages $0.08 \%$ of donors' GDP, or $29 \%$ of all aid disbursements. Other recipient countries in our sample receive $25 \%$ of all aid. For likely similar reasons as above, commitments appear higher on average than actual disbursements.

7. Aid outflows are very volatile. The magnitude of the fluctuations in ODA disbursements is on average almost nine times that of donors' output. Disbursements to our African sample are eleven times as volatile as donors' output (Table 3).

8. Overall aid outflows are procyclical, but aid disbursements to recipients in our sample are not. While a few donors have aid policies that are uncorrelated, or even negatively correlated (France and Italy) with their business cycle, donors tend to give more in good times: the comovements of total aid 
disbursements with donors' output are positive for $72 \%$ of donors (Table 7). For $85 \%$ of these, aid disbursements lag their cycle.

Donors, however, do not give in a procyclical fashion to recipients in our sample: for African recipients, only $39 \%$ of donors do (they account for only $20 \%$ of bilateral flows to these countries, and $21 \%$ of bilateral flows to those recipients whose aid inflows we report as procyclical); for non-African recipients, $33 \%$ of donors give in a procyclical way. Therefore, it seems unlikely that the positive correlation between recipients' GDP and aid receipts can be explained by the positive comovements of North and South business cycles documented in Kouparitsas (1998) and Agénor et al. (1999).

What shall we make of all these facts? The first message from our results is that aid is a very important source of income for recipient countries. If one is interested in economic outcomes in these countries, then one should certainly think about the role played by foreign aid.

Second, the magnitude of output fluctuations experienced by these countries is much stronger than that of industrialized countries in the postwar period. This fact is not new, though we extend previous estimates of output volatility to a much larger set of developing countries. What is rather striking, however, is the fact that foreign aid is even more volatile than recipient GDP and, especially in Africa, moves in a procyclical fashion. Because of the intense variability of output, the welfare implications of any mechanism to smooth out the impact of output fluctuations on consumption are likely to be large. One might think of aid flows as one such mechanism, among others such as domestic savings. The procyclicality of aid receipts, however, suggests that aid flows per se do not play that role. Of course, it can rightly be argued that, except for some components of aid such as food aid, consumption smoothing is not the main purpose of foreign aid. Another, obvious role of foreign aid is to foster the economic development of recipient countries. The high variability of output in these countries, however, might be an important handicap for economic growth, as the results of Ramey \& Ramey (1995) have shown. In that case, the procyclicality of aid flows, by intensifying the volatility of disposable income, might hurt growth. Clearly, this discussion goes beyond the scope of this paper, but it illustrates well the importance of the facts we report here. If one is interested in the welfare or the growth of recipient countries, one cannot not be interested in the pattern of disbursements.

Another message from our results is that Africa is special in many respects. That region of the world is the one for which aid matters most. It is also the region for which aid receipts are most often and most strongly procyclical. Although Africa represents a relatively small fraction of donors' aid effort, aid is a very significant share of income in that part of the world. Finally, Africa is special among all aid recipients, in that donors have different aid policies to Africa than to the rest: while total aid disbursements are procyclical from the donors' perspective, such is not the case for aid disbursements to Africa. 


\section{Discussion and conclusion}

In this section, we discuss possible explanations for the procyclicality of aid.

A first, simple explanation is that aid may feed into the recipient's output. If such a multiplier effect is not immediate, one would expect to observe aid receipts leading the cycle. Our results, however, show that this is almost never the case. If such feedback is rapid, one would expect the contemporaneous correlation of aid and output to be directly related to the importance of aid relative to the recipient's domestic income. Yet, while we do find procyclical aid receipts for the three countries that depend most heavily on aid, we document even stronger aid procyclicality for some other countries that depend much less on aid. Indeed, once those three extreme cases are removed from our sample, we find no statistically significant relation between the aid-output correlation and the recipients' average aid-output ratio (a measure of aid dependency). Overall, then, our findings suggest the need for additional explanations of aid procyclicality.

Domestic political or fiscal considerations may lead donor countries to adjust aid flows to their own business cycle. As a result, donors may disburse procyclically, which, given a positive correlation between NorthSouth business cycles, might lead to procyclical aid receipts. And indeed, total aid disbursements by donors were shown to be procyclical for a vast majority of donors. Yet, when we looked at disbursements to the countries in our recipient sample, we found that they were typically not procyclical from the perspective of donors.

Alesina \& Dollar (1998) make a case that bilateral aid policies are conditioned on political, much more than other, factors. Their results show that, in particular, former colonial ties are a big determinant of foreign aid policy. Why this would lead to procyclical aid flows is unclear. In any case, we find similar patterns of bilateral aid procyclicality among former African colonies of France and the United Kingdom.

Aid disbursements could also be conditioned on the periodic observation of some indicator of good economic performance, in which case aid flows would be procyclical - contemporaneously or with a lag, depending on the periodicity of the monitoring. On the other hand, one might also make the argument that aid could be conditional on the adoption by the recipient of some policies, such as compliance with an IMF structural adjustment program. In the latter case, aid would rather be expected to be countercyclical, since such programs often entail short-term costs in terms of output. Of the twelve countries in our African sample classified as IMF sustained adjusters, however, only two experienced countercyclical aid inflows (Tanzania and Mali); for most of the others, aid was procyclical.

Another possible explanation is that some donors require matching grants by the recipient. To the extent that the latter has more resources during cyclical upturns, some procyclicality of foreign aid disbursements may 
follow from such donor requirements. This effect may be reinforced if, in cyclical downturns, recipients are held to strict budget deficit targets by international organizations and foreign grants are not taken into account when computing these targets (as is sometimes the International Monetary Fund's practice in Africa). The effect might also be reinforced if bilateral aid agencies condition their assistance on multilateral aid.

Many competing explanations may have a part in the cyclical behavior of aid receipts. Given the likely important welfare and growth consequences of volatile and procyclical aid receipts, the facts we report in this paper seem to stand as an interesting anomaly to be explained. How much of the facts can be rationalized by any theory is a sound question. Such a quantitative assessment would require the construction of a model of foreign aid policy, which the empirical regularities we have reported here only purport to guide. 


\section{References}

Agénor, P., McDermott, C., \& Prasad, E. (1999). Macroeconomic fluctuations in developing countries: some stylized facts. IMF Working Paper, No. 99-35.

Alesina, A. \& Dollar, D. (1998). Who gives foreign aid to whom and why. NBER Working Paper, No. 6612.

Ambler, S., Cardia, E., \& Zimmermann, C. (1999). International business cycles: what are the facts? Working Paper Nr. 90: Center for Research on Economic Fluctuations and Employment, UQAM.

Atkeson, A. (1991). International lending with moral hazard and risk of repudiation. Econometrica, 59(4), 1069-1089.

Backus, D. K. \& Kehoe, P. J. (1992). International evidence on the historical properties of business cycles. American Economic Review, 82(4), 864-888.

Baxter, M. \& King, R. G. (1995). Measuring business cycles: approximate band-pass filters for economic time series. NBER Working Paper 5022.

Boone, P. (1994). The impact of foreign aid on savings and growth. Center for Economic Performance Working Paper 1265, London, October.

Boone, P. (1996). Politics and the effectiveness of aid. European Economic Review, 40(2), 289-329.

Burnside, C. \& Dollar, D. (1997). Aid, policies and growth. Working Paper 1777, The World Bank: Policy Research Department.

Carmichael, B., Samson, L., \& Keita, S. (1999). Liquidity constraints and business cycles in developing economies. Review of Economic Dynamics. Forthcoming.

Chadha, B. \& Prasad, E. (1994). Are prices countercyclical? Evidence from the G-7. Journal of Monetary Economics, $34,239-257$.

Chang, C. C., Fernandez-Arias, E., \& Serven, L. (1998). Measuring aid flows: a new approach. Manuscript. World Bank.

Cooley, T. F. \& Ohanian, L. E. (1991). The cyclical behavior of prices. Journal of Monetary Economics, 28, $25-60$.

Cooley, T. \& Prescott, E. (1995). Economic growth and business cycles. In Frontiers of Business Cycle Research. T.F. Cooley Editor. Princeton.

Easterly, W. (1999). The ghost of financing gap: Testing the growth model used in international financial institutions. Journal of Development Economics, 60(2), 423-438.

Fiorito, R. \& Kollintzas, T. (1994). Stylized facts of business cycles in the G7 from a real business cycles perspective. European Economic Review, 38, 235-269.

Hamilton, J. D. (1989). A new approach to the economic analysis of nonstationary time series and the business cycle. Econometrica, 57(2), 357-384.

Hansen, H. \& Tarp, F. (2000). Aid and growth regressions. Mimeo, DERG, University of Copenhagen.

Hodrick, R. J. \& Prescott, E. C. (1980). Postwar US business cycles: an empirical investigation. Discussion Paper 451. Carnegie-Mellon University.

Kouparitsas, M. A. (1998). North-South business cycles. Working Paper. Federal Reserve Bank of Chicago.

Krueger, A., Michalopoulos, C., \& Ruttan, V. (1989). Aid and Development. Baltimore: Johns Hopkins University Press.

Kydland, F. E. \& Prescott, E. C. (1982). Time to build and aggregate fluctuations. Econometrica, 50(6), 1345-1370.

Kydland, F. E. \& Prescott, E. C. (1990). Business cycles: Real facts and a monetary myth. Federal Reserve Bank of Minneapolis Quarterly Review, 14, (Spring), 3-18.

Lane, P. R. (1999). Do international investment income flows smooth income?. Discussion Paper 2123: CEPR. 
Lensink, R. \& Morrissey, O. (1999). Uncertainty of aid inflows and the aid-growth relationship. Working Paper \#99/3: Center for Research in Economic Development and International Trade, University of Nottingham.

Lucas, R. E. (1977). Understanding business cycles. Carnegie Rochester Conference Series on Public Policy, 5, 7-29. eds. Karl Brunner and Alan H. Metzer, Amsterdam: North Holland Publishing. Reprinted in Studies in Business Cycle Theory, MIT Press, (1981), 215-39.

Marcet, A. \& Marimon, R. (1992). Communication, commitment and growth. Journal of Economic Theory, 58(2), 219-49.

Mendoza, E. (1992). The terms of trade and economic fluctuations. IMF Working Paper 92-98a.

Mendoza, E. (1995). The terms of trade, the real exchange rate, and economic fluctuations. International Economic Review, 36(1), 101-137.

OECD (1998). Statistical Compendium 1998-2 (CD-ROM). Paris: Organization for Economic Co-operation and Development.

OECD (1999). Geographical Distribution of Financial Flows to Aid Recipients: 1960-1997 (CD-ROM). Paris: Organization for Economic Co-operation and Development.

Ramey, G. \& Ramey, V. A. (1995). Cross-country evidence of the link between volatility and growth. American Economic Review, 85(5), 1138-1151.

Stryker, J. \& Tuluy, H. (1989). Assitance to Ghana and the Ivory Coast. In Aid and Development. Krueger, A., Michalopoulos, C. \& Ruttan, V. Editors. Baltimore: Johns Hopkins University Press.

Summers, R. \& Heston, A. (1991). The Penn World Table (Mark 5): an expanded set of international comparisons, 1950-1988. Quarterly Journal of Economics, 327-368.

Svensson, J. (1995). When is foreign aid policy credible? Aid dependence and conditionality. Working Paper: Stockholm University, October.

Talvi, E. \& Végh, C. A. (1998). Tax base variability and procyclical fiscal policy. Working Paper: UCLA.

World Bank (1994). World Data (CD-ROM). Washington: World Bank.

World Bank (1995). World Data (CD-ROM). Washington: World Bank.

World Bank (1998). World Development Indicators (CD-ROM). Washington: World Bank. 
Table 1: Importance of foreign aid to recipients - Panel I: Africa

\begin{tabular}{|c|c|c|c|c|c|c|}
\hline & \multicolumn{6}{|c|}{ Mean fraction of recipient's GDP (\%) } \\
\hline & \multicolumn{3}{|c|}{ Net receipts } & \multicolumn{3}{|c|}{ Commitments } \\
\hline & ODA & Mult & Bilat & ODA & Mult & Bilat \\
\hline Benin & 9.2 & 4.0 & 5.1 & 11.6 & 5.2 & 6.3 \\
\hline Botswana & 9.8 & 1.9 & 7.7 & 12.7 & 2.5 & 10.0 \\
\hline Burkina Faso & 13.1 & 4.6 & 8.4 & 15.9 & 6.0 & 9.5 \\
\hline Burundi & 15.9 & 7.8 & 7.9 & 18.2 & 9.6 & 8.2 \\
\hline Cameroon & 4.0 & 1.1 & 2.8 & 5.0 & 1.3 & 3.7 \\
\hline Cape Verde & 47.2 & 15.1 & 31.3 & 57.1 & 19.9 & 35.5 \\
\hline Central Afr. Rep. & 12.9 & 5.0 & 7.8 & 14.3 & 5.7 & 8.5 \\
\hline Chad & 16.2 & 6.8 & 9.1 & 18.7 & 8.5 & 10.1 \\
\hline Congo & 6.3 & 1.6 & 4.5 & 7.1 & 1.9 & 5.1 \\
\hline Côte d'Ivoire & 4.1 & 1.3 & 2.9 & 5.3 & 1.3 & 3.9 \\
\hline Egypt & 7.4 & 1.1 & 3.9 & 7.8 & 0.8 & 6.5 \\
\hline Gabon & 2.8 & 0.5 & 2.2 & 3.3 & 0.5 & 2.7 \\
\hline Gambia & 22.9 & 10.1 & 12.0 & 26.9 & 12.3 & 13.8 \\
\hline Ghana & 5.9 & 2.7 & 3.1 & 7.6 & 3.4 & 4.1 \\
\hline Guinea Bissau & 44.2 & 17.2 & 25.1 & 49.5 & 22.2 & 25.4 \\
\hline Kenya & 7.1 & 2.1 & 4.9 & 8.6 & 2.5 & 6.0 \\
\hline Lesotho & 22.6 & 8.9 & 13.6 & 27.1 & 11.7 & 15.2 \\
\hline Liberia & 6.0 & 1.7 & 4.2 & 7.1 & 2.2 & 4.9 \\
\hline Madagascar & 7.3 & 2.9 & 4.2 & 8.8 & 4.0 & 4.8 \\
\hline Malawi & 16.5 & 8.0 & 8.6 & 20.3 & 9.6 & 10.7 \\
\hline Mali & 16.8 & 6.5 & 9.5 & 19.9 & 8.0 & 11.1 \\
\hline Mauritania & 22.2 & 7.6 & 8.4 & 22.1 & 9.3 & 9.4 \\
\hline Mauritius & 2.9 & 0.8 & 2.1 & 4.0 & 1.2 & 2.7 \\
\hline Morocco & 3.1 & 0.4 & 1.7 & 3.4 & 0.5 & 2.2 \\
\hline Niger & 11.9 & 3.9 & 7.5 & 13.4 & 4.6 & 8.3 \\
\hline Nigeria & 0.5 & 0.2 & 0.4 & 0.8 & 0.3 & 0.4 \\
\hline Rwanda & 12.7 & 4.4 & 8.1 & 14.6 & 6.0 & 8.5 \\
\hline Senegal & 11.0 & 3.4 & 7.0 & 12.7 & 4.1 & 7.8 \\
\hline Seychelles & 14.2 & 1.3 & 12.7 & 18.4 & 2.3 & 15.4 \\
\hline Sierra Leone & 4.8 & 1.9 & 2.8 & 6.7 & 2.6 & 3.9 \\
\hline Somalia & 34.2 & 12.4 & 14.9 & 36.4 & 14.4 & 18.8 \\
\hline Sudan & 6.3 & 2.1 & 2.7 & 6.8 & 2.6 & 3.1 \\
\hline Swaziland & 6.9 & 2.3 & 4.6 & 9.0 & 2.9 & 6.1 \\
\hline Tanzania & 16.8 & 4.4 & 12.3 & 20.8 & 6.3 & 14.3 \\
\hline Togo & 10.7 & 4.4 & 6.2 & 12.4 & 5.1 & 7.2 \\
\hline Tunisia & 3.6 & 0.6 & 2.7 & 5.2 & 0.8 & 3.9 \\
\hline Zaire & 3.7 & 1.2 & 2.5 & 4.2 & 1.4 & 2.8 \\
\hline Zambia & 12.5 & 4.5 & 7.9 & 13.0 & 4.0 & 8.9 \\
\hline Average & 12.5 & 4.4 & 7.5 & 14.7 & 5.5 & 8.7 \\
\hline Median & 10.3 & 3.2 & 6.6 & 12.6 & 4.0 & 7.5 \\
\hline Standard Deviation & 10.6 & 4.1 & 6.2 & 12.1 & 5.2 & 6.8 \\
\hline
\end{tabular}


Table 1 - Panel II: Non-African recipients

\begin{tabular}{|c|c|c|c|c|c|c|}
\hline & \multicolumn{6}{|c|}{ Mean fraction of recipient's GDP (\%) } \\
\hline & \multicolumn{3}{|c|}{ Net receipts } & \multicolumn{3}{|c|}{ Commitments } \\
\hline & $\overline{\mathrm{ODA}}$ & Mult & Bilat & $\overline{\mathrm{ODA}}$ & Mult & Bilat \\
\hline Bangladesh & 8.1 & 3.1 & 4.7 & 10.5 & 4.3 & 5.9 \\
\hline Bolivia & 6.6 & 2.2 & 4.3 & 8.6 & 3.2 & 5.4 \\
\hline Costa Rica & 2.7 & 0.5 & 2.2 & 3.3 & 0.8 & 2.5 \\
\hline Dominican Rep. & 1.6 & 0.5 & 1.1 & 2.3 & 0.9 & 1.4 \\
\hline Ecuador & 1.3 & 0.5 & 0.8 & 1.9 & 0.8 & 1.1 \\
\hline Guatemala & 1.5 & 0.4 & 1.1 & 2.0 & 0.7 & 1.3 \\
\hline Guyana & 10.3 & 6.3 & 4.0 & 14.8 & 8.1 & 6.7 \\
\hline Haiti & 8.2 & 2.6 & 5.7 & 10.2 & 4.1 & 6.2 \\
\hline Honduras & 6.0 & 2.1 & 3.9 & 8.1 & 3.3 & 4.7 \\
\hline India & 1.0 & 0.4 & 0.6 & 1.4 & 0.6 & 0.8 \\
\hline Indonesia & 1.9 & 0.2 & 1.7 & 2.9 & 0.3 & 2.5 \\
\hline Jamaica & 3.8 & 0.6 & 3.2 & 5.3 & 1.0 & 4.4 \\
\hline Jordan & 16.0 & 1.3 & 4.3 & 14.6 & 1.8 & 5.4 \\
\hline Malaysia & 0.6 & 0.1 & 0.6 & 1.0 & 0.1 & 0.9 \\
\hline Mexico & 0.1 & 0.0 & 0.1 & 0.1 & 0.0 & 0.1 \\
\hline Nepal & 7.6 & 3.2 & 4.4 & 9.9 & 5.0 & 4.9 \\
\hline Pakistan & 3.5 & 1.1 & 2.0 & 4.6 & 1.6 & 2.9 \\
\hline Panama & 1.4 & 0.4 & 1.0 & 1.8 & 0.6 & 1.2 \\
\hline Paraguay & 2.0 & 0.8 & 1.2 & 2.9 & 1.3 & 1.6 \\
\hline Peru & 1.1 & 0.2 & 0.9 & 1.3 & 0.3 & 1.0 \\
\hline Philippines & 1.6 & 0.2 & 1.4 & 2.3 & 0.2 & 2.1 \\
\hline Salvador & 4.7 & 1.0 & 3.7 & 6.1 & 1.4 & 4.6 \\
\hline Sri Lanka & 6.5 & 2.1 & 4.3 & 8.5 & 2.8 & 5.6 \\
\hline Thailand & 0.9 & 0.1 & 0.7 & 1.2 & 0.2 & 1.1 \\
\hline Uruguay & 0.4 & 0.1 & 0.3 & 0.5 & 0.2 & 0.4 \\
\hline Average & 4.0 & 1.2 & 2.3 & 5.1 & 1.7 & 3.0 \\
\hline Median & 2.0 & 0.5 & 1.7 & 2.9 & 0.9 & 2.5 \\
\hline Standard Deviation & 3.9 & 1.4 & 1.7 & 4.4 & 2.0 & 2.1 \\
\hline
\end{tabular}

Notes: GDP is the gross domestic product in US\$ (Source: World Bank). ODA is the official development assistance, in US\$ (Source: OECD). Mult and Bilat are the multilateral and bilateral components of ODA. All series are expressed in per capita terms and deflated using the implicit imports deflator (Source: World Bank) or, when missing, the UNCTAD's imports price index. Each number corresponds to the average ratio of the relevant series over the period 1969-95, except for Burundi (1972-95), Cape Verde (1975-93), Guinea Bissau (1974-95), Liberia and Somalia (1969-89), Niger, Rwanda, Seychelles, Tanzania and Zaire (1969-93), Sierra Leone (1969-90), Sudan (1969-91), Bangladesh (1972-95), Bolivia and Guyana (1969-94), and Jordan (1976-95). 
Table 2: Volatility of output and foreign aid to recipients - Panel I: Africa

\begin{tabular}{|c|c|c|c|c|c|c|c|}
\hline & \multicolumn{7}{|c|}{ Standard deviation (\%) } \\
\hline & \multirow[b]{2}{*}{ GDP } & \multicolumn{3}{|c|}{ Net receipts } & \multicolumn{3}{|c|}{ Commitments } \\
\hline & & ODA & Mult & Bilat & ODA & Mult & Bilat \\
\hline Benin & 11.1 & 17.0 & 18.0 & 20.6 & 28.4 & 40.7 & 40.3 \\
\hline Botswana & 10.4 & 16.2 & 31.6 & 19.6 & 25.0 & 35.1 & 34.3 \\
\hline Burkina Faso & 9.1 & 17.4 & 27.5 & 14.0 & 14.5 & 41.4 & 18.9 \\
\hline Burundi & 8.6 & 8.7 & 17.8 & 10.0 & 23.9 & 44.5 & 21.9 \\
\hline Cameroon & 10.2 & 26.5 & 57.7 & 24.3 & 23.2 & 53.6 & 26.2 \\
\hline Cape Verde & 11.1 & 21.8 & 38.0 & 24.4 & 21.2 & 40.8 & 20.0 \\
\hline Central Afr. Rep. & 10.7 & 15.3 & 28.4 & 16.1 & 24.5 & 54.7 & 21.9 \\
\hline Chad & 13.6 & 33.6 & 38.7 & 33.9 & 42.7 & 58.5 & 38.7 \\
\hline Congo & 19.2 & 20.6 & 33.5 & 23.2 & 39.5 & 64.4 & 41.2 \\
\hline Côte d'Ivoire & 10.7 & 15.1 & 62.2 & 14.5 & 25.2 & 61.9 & 25.3 \\
\hline Egypt & 13.7 & 48.2 & 61.3 & 49.2 & 46.7 & 44.5 & 48.6 \\
\hline Gabon & 23.3 & 25.9 & 50.9 & 27.8 & 42.1 & 79.7 & 41.9 \\
\hline Gambia & 14.4 & 24.9 & 29.2 & 25.8 & 36.1 & 50.8 & 32.3 \\
\hline Ghana & 30.8 & 39.1 & 37.9 & 44.1 & 39.8 & 54.2 & 45.7 \\
\hline Guinea Bissau & 20.7 & 22.6 & 17.4 & 46.3 & 37.9 & 49.6 & 46.4 \\
\hline Kenya & 9.2 & 16.6 & 37.6 & 13.8 & 28.0 & 52.0 & 30.1 \\
\hline Lesotho & 10.5 & 14.5 & 18.5 & 16.3 & 29.1 & 39.8 & 30.0 \\
\hline Liberia & 6.4 & 23.3 & 27.4 & 35.0 & 31.1 & 73.4 & 32.3 \\
\hline Madagascar & 10.1 & 20.1 & 24.0 & 22.2 & 24.3 & 32.9 & 25.7 \\
\hline Malawi & 10.7 & 17.6 & 24.0 & 22.1 & 30.4 & 44.9 & 38.5 \\
\hline Mali & 10.1 & 17.2 & 16.3 & 21.8 & 23.0 & 29.9 & 30.1 \\
\hline Mauritania & 8.9 & 33.4 & 33.4 & 26.0 & 24.9 & 35.9 & 18.5 \\
\hline Mauritius & 9.4 & 26.7 & na & 27.6 & 39.8 & 63.4 & 50.9 \\
\hline Morocco & 10.3 & 37.9 & 59.5 & 22.0 & 26.7 & 62.1 & 21.7 \\
\hline Niger & 12.3 & 20.5 & 27.4 & 19.4 & 22.7 & 50.6 & 21.1 \\
\hline Nigeria & 25.5 & 31.7 & 41.7 & 44.0 & 48.9 & 49.3 & 57.3 \\
\hline Rwanda & 9.8 & 17.7 & 21.5 & 18.3 & 23.5 & 42.9 & 31.1 \\
\hline Senegal & 12.8 & 18.5 & 40.9 & 14.9 & 21.2 & 37.5 & 18.1 \\
\hline Seychelles & 11.2 & 28.7 & 51.1 & 31.5 & 41.2 & 96.5 & 36.8 \\
\hline Sierra Leone & 19.0 & 37.6 & 34.9 & 50.7 & 45.1 & 67.0 & 48.1 \\
\hline Somalia & 17.6 & 33.3 & 27.0 & 52.1 & 36.6 & 29.4 & 64.5 \\
\hline Sudan & 17.8 & 30.7 & 17.4 & na & 40.1 & 32.3 & 41.1 \\
\hline Swaziland & 6.0 & 33.3 & 19.1 & 52.9 & 40.3 & 60.6 & 42.9 \\
\hline Tanzania & 15.8 & 14.8 & 29.3 & 14.0 & 26.6 & 39.3 & 25.6 \\
\hline Togo & 14.2 & 26.3 & 38.9 & 26.8 & 41.0 & 55.0 & 42.0 \\
\hline Tunisia & 4.6 & 22.5 & 28.6 & 24.9 & 28.1 & 42.5 & 30.1 \\
\hline Zaire & 17.9 & 30.8 & 40.2 & 30.2 & 37.2 & 47.8 & 46.8 \\
\hline Zambia & 13.9 & 31.5 & 59.0 & 32.4 & 43.2 & 57.5 & 44.9 \\
\hline Average & 13.2 & 24.7 & 34.3 & 27.4 & 32.2 & 50.4 & 35.0 \\
\hline Median & 11.1 & 23.0 & 31.6 & 24.4 & 29.8 & 49.5 & 33.3 \\
\hline Standard-Deviation & 5.5 & 8.6 & 13.6 & 12.0 & 8.8 & 14.3 & 11.6 \\
\hline
\end{tabular}


Table 2 - Panel II: Non-African recipients

\begin{tabular}{|c|c|c|c|c|c|c|c|}
\hline & \multicolumn{7}{|c|}{ Standard deviation (\%) } \\
\hline & \multirow[b]{2}{*}{ GDP } & \multicolumn{3}{|c|}{ Net receipts } & \multicolumn{3}{|c|}{ Commitments } \\
\hline & & ODA & Mult & Bilat & ODA & Mult & Bilat \\
\hline Bangladesh & 17.0 & 21.4 & 21.8 & 23.3 & 19.5 & 23.4 & 22.7 \\
\hline Bolivia & 14.0 & 17.8 & 18.0 & 24.1 & 36.8 & 52.6 & 42.9 \\
\hline Costa Rica & 18.4 & 29.8 & 30.1 & 40.4 & 38.9 & 57.9 & 49.9 \\
\hline Dominican Rep. & 19.4 & 62.9 & 62.1 & na & 48.3 & 95.6 & 47.6 \\
\hline Ecuador & 11.0 & 25.6 & 33.9 & 29.2 & 30.8 & 55.5 & 34.5 \\
\hline Guatemala & 8.9 & 26.3 & 34.2 & 31.8 & 42.6 & 107.6 & 44.9 \\
\hline Guyana & 14.8 & 37.7 & 53.7 & 31.7 & 71.4 & 91.2 & 77.5 \\
\hline Haiti & 6.6 & 36.0 & 40.2 & 31.6 & 39.1 & 58.8 & 37.4 \\
\hline Honduras & 9.2 & 19.3 & 37.7 & 20.0 & 43.2 & 62.0 & 43.1 \\
\hline India & 11.0 & 19.9 & 26.8 & 25.3 & 19.1 & 21.6 & 29.3 \\
\hline Indonesia & 7.6 & 20.3 & 28.7 & 22.5 & 33.1 & 62.6 & 33.0 \\
\hline Jamaica & 15.2 & 29.8 & 43.1 & 31.0 & 32.8 & 72.8 & 39.5 \\
\hline Jordan & 10.0 & 41.8 & 59.8 & 45.7 & 50.8 & 54.6 & 54.2 \\
\hline Malaysia & 6.5 & 36.7 & 37.2 & 38.8 & 50.6 & 42.3 & 52.2 \\
\hline Mexico & 16.4 & 39.2 & na & na & 52.5 & 46.3 & 62.5 \\
\hline Nepal & 11.1 & 18.8 & 17.3 & 21.0 & 28.9 & 42.3 & 30.0 \\
\hline Pakistan & 13.4 & 20.0 & 24.1 & 25.2 & 23.4 & na & 33.1 \\
\hline Panama & 12.2 & 43.8 & na & 51.3 & 74.2 & 84.0 & 86.0 \\
\hline Paraguay & 25.8 & 33.7 & 62.5 & 34.2 & 43.0 & 90.5 & 45.7 \\
\hline Peru & 13.3 & 25.5 & 36.9 & 28.9 & 27.6 & 67.0 & 32.0 \\
\hline Philippines & 9.0 & 26.9 & 46.4 & 30.6 & 36.0 & 61.6 & 35.8 \\
\hline Salvador & 11.7 & 17.9 & 37.2 & 28.5 & 34.4 & 68.6 & 45.1 \\
\hline Sri Lanka & 13.3 & 16.6 & 23.6 & 18.7 & 23.5 & 47.5 & 25.7 \\
\hline Thailand & 6.8 & 20.5 & 40.0 & 20.2 & 33.7 & 47.6 & 38.5 \\
\hline Uruguay & 19.6 & 49.6 & na & 58.7 & 57.7 & 94.8 & 63.1 \\
\hline Average & 12.9 & 29.5 & 37.1 & 31.0 & 39.7 & 62.9 & 44.3 \\
\hline Median & 12.2 & 26.3 & 37.1 & 29.2 & 36.8 & 60.2 & 42.9 \\
\hline Standard Deviation & 4.7 & 11.7 & 13.4 & 10.2 & 14.3 & 22.2 & 15.3 \\
\hline
\end{tabular}

Notes: GDP is the gross domestic product in US\$ (Source: World Bank). ODA is the official development assistance, in US\$ (Source: OECD). Mult and Bilat are the multilateral and bilateral components of ODA. All series are expressed in per capita terms and deflated using the implicit imports deflator (Source: World Bank) or, when missing, the UNCTAD's imports price index. The period is 1969-95, except for Burundi (1972-95), Cape Verde (1975-93), Guinea Bissau (1974-95), Liberia and Somalia (1969-89), Niger, Rwanda, Seychelles, Tanzania and Zaire (1969-93), Sierra Leone (1969-90), Sudan (1969-91), Bangladesh (1972-95), Bolivia and Guyana (1969-94), and Jordan (1976-95). Sample moments are computed from the cyclical component of the Hodrick-Prescott filtered logarithms of the series. A "na" is reported when the original series included non-positive numbers. 
Table 3: Volatility of donors' output and foreign aid (1969-1995)

\begin{tabular}{|c|c|c|c|c|c|c|c|}
\hline \multirow[b]{3}{*}{ Donor country } & \multicolumn{7}{|c|}{ Standard deviations (\%) } \\
\hline & \multirow[b]{2}{*}{ GDP } & \multicolumn{3}{|c|}{ Net ODA Disbursements } & \multicolumn{3}{|c|}{ ODA Commitments } \\
\hline & & Total & Africa & Others & Total & Africa & Others \\
\hline Australia & 1.83 & 8.39 & 36.67 & 14.30 & 20.05 & 38.01 & 33.82 \\
\hline Austria & 1.48 & 31.88 & 75.35 & na & 53.83 & 108.59 & 81.75 \\
\hline Belgium & 1.84 & 7.35 & 7.18 & 24.01 & 17.85 & 90.27 & 31.34 \\
\hline Canada & 2.62 & 9.37 & 13.39 & 14.81 & 20.79 & 36.31 & 25.69 \\
\hline Denmark & 1.95 & 7.03 & 10.90 & 16.59 & 18.97 & 31.11 & 37.62 \\
\hline Finland & 3.86 & 19.37 & 21.79 & 71.24 & 30.46 & 35.36 & 78.98 \\
\hline France & 1.57 & 8.24 & 8.38 & 20.05 & 12.71 & 15.06 & 26.97 \\
\hline Germany & 1.71 & 9.84 & 14.29 & 16.49 & 15.26 & 19.97 & 16.12 \\
\hline Ireland & 2.87 & 23.13 & 24.41 & 31.10 & 23.25 & 24.40 & 31.10 \\
\hline Italy & 1.83 & 115.36 & na & na & 49.31 & 57.27 & 74.30 \\
\hline Japan & 2.15 & 12.06 & 39.26 & 15.06 & 16.88 & 54.74 & 20.09 \\
\hline Netherlands & 1.75 & 9.60 & 14.95 & 16.28 & 17.54 & 27.37 & 25.10 \\
\hline New Zealand & 2.84 & 13.64 & 66.05 & 28.44 & na & na & na \\
\hline Norway & 1.78 & 9.83 & 13.18 & 14.90 & 19.79 & 33.16 & 40.51 \\
\hline Sweden & 2.05 & 11.61 & 17.03 & 25.91 & 17.37 & 28.19 & 34.91 \\
\hline Switzerland & 2.40 & 10.23 & 15.22 & 21.72 & 20.90 & 36.11 & 45.48 \\
\hline United Kingdom & 2.68 & 10.19 & 16.21 & 16.67 & 19.72 & 27.35 & 38.14 \\
\hline United States & 2.18 & 9.94 & 28.41 & 16.71 & 21.86 & 50.21 & 19.52 \\
\hline Average & 2.19 & 18.17 & 24.86 & 22.77 & 23.33 & 41.97 & 38.91 \\
\hline Median & 2.00 & 10.07 & 16.21 & 16.69 & 19.79 & 35.36 & 33.82 \\
\hline Standard deviation & 0.60 & 25.07 & 19.53 & 13.95 & 11.30 & 24.61 & 20.40 \\
\hline
\end{tabular}

Notes: GDP is the gross domestic product per capita in constant local currency $(1990=100)$. ODA stands for official development assistance per capita in constant local currency; current US $\$$ amounts are converted into constant local currency using current exchange rates and local GDP deflators. All data are from the OECD. Total stands for aid flows to all aid recipients worldwide, whether in our sample or not; Africa, for aid flows to the 38 African countries in our recipient sample; Others, for aid flows to the 25 non-African recipients in the sample. The period is 1969-95, except for Austria (1971-95), Belgium and Netherlands (1970-95), Germany (West Germany, 1969-90), Ireland (197493) and New Zealand (1972-95). Sample moments are computed from the cyclical component of the Hodrick-Prescott filtered logarithms of the series. A "na" is reported when the original series included non-positive numbers. 
Table 4: Cyclical properties of aid from the recipient point of view - Summary table

\begin{tabular}{|c|c|c|c|c|c|c|}
\hline \multirow[t]{3}{*}{ 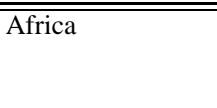 } & \multicolumn{6}{|c|}{ Comovement with recipients' GDP } \\
\hline & \multicolumn{2}{|c|}{ ODA } & \multicolumn{2}{|c|}{ Mult } & \multicolumn{2}{|c|}{ Bilat } \\
\hline & $\mathrm{R}$ & $\mathrm{C}$ & $\mathrm{R}$ & $\mathrm{C}$ & $\mathrm{R}$ & $\mathrm{C}$ \\
\hline Benin & $+{ }_{l}$ & 0 & $+{ }_{l}$ & 0 & $+_{l}$ & $+_{l}$ \\
\hline Botswana & + & 0 & 0 & $+l$ & $+l$ & 0 \\
\hline Burkina Faso & + & $+_{L}$ & + & $+{ }_{L}$ & + & + \\
\hline Burundi & $+{ }_{L}$ & $+_{L}$ & $+L$ & $+L$ & 0 & 0 \\
\hline Cameroon & $+_{L}$ & + & + & + & $+_{L}$ & 0 \\
\hline Cape Verde & + & + & + & + & + & 0 \\
\hline Central Afr. Rep. & 0 & 0 & 0 & 0 & 0 & 0 \\
\hline Chad & + & + & + & + & $+{ }_{L}$ & + \\
\hline Congo & 0 & 0 & + & 0 & $+_{L}$ & 0 \\
\hline Côte d'Ivoire & $+{ }_{L}$ & 0 & $+_{L}$ & 0 & 0 & 0 \\
\hline Egypt & 0 & 0 & 0 & 0 & 0 & 0 \\
\hline Gabon & 0 & 0 & - & 0 & + & 0 \\
\hline Gambia & $+l$ & $+l$ & $+l$ & $+l$ & + & $+l$ \\
\hline Ghana & + & + & $+{ }_{l}$ & + & + & + \\
\hline Guinea Bissau & + & 0 & + & $+{ }_{L}$ & 0 & 0 \\
\hline Kenya & $+L$ & + & $+L$ & 0 & $+_{L}$ & + \\
\hline Lesotho & + & $+l$ & + & $+l$ & $+L$ & $+l$ \\
\hline Liberia & 0 & + & $+_{L}$ & + & 0 & 0 \\
\hline Madagascar & + & $+{ }_{L}$ & 0 & $+{ }_{L}$ & + & $+_{L}$ \\
\hline Malawi & 0 & 0 & + & 0 & 0 & 0 \\
\hline Mali & - & 0 & - & 0 & 0 & 0 \\
\hline Mauritania & + & - & + & 0 & $+_{l}$ & + \\
\hline Mauritius & + & 0 & na & 0 & + & 0 \\
\hline Morocco & $+{ }_{L}$ & - & $+{ }_{L}$ & 0 & $+l$ & $+l$ \\
\hline Niger & 0 & 0 & $+l$ & $+_{l}$ & 0 & 0 \\
\hline Nigeria & 0 & 0 & + & 0 & 0 & 0 \\
\hline Rwanda & + & + & + & + & + & 0 \\
\hline Senegal & $+_{L}$ & + & + & $+{ }_{L}$ & + & + \\
\hline Seychelles & + & $+l$ & $+_{l}$ & $+_{l}$ & + & 0 \\
\hline Sierra Leone & + & $+l$ & + & $+{ }_{L}$ & + & $+_{l}$ \\
\hline Somalia & + & + & $+l$ & + & + & + \\
\hline Sudan & $+l$ & 0 & 0 & - & na & $+_{L}$ \\
\hline Swaziland & 0 & $+_{L}$ & 0 & 0 & 0 & $+{ }_{L}$ \\
\hline Tanzania & - & - & $+_{l}$ & - & - & - \\
\hline Togo & + & + & + & + & + & + \\
\hline Tunisia & 0 & 0 & 0 & 0 & 0 & 0 \\
\hline Zaire & + & $+_{L}$ & + & + & + & $+_{L}$ \\
\hline Zambia & $+l$ & $+l$ & $+l$ & $+l$ & $+l$ & $+l$ \\
\hline
\end{tabular}

\begin{tabular}{|c|c|c|c|c|c|c|}
\hline \multirow{3}{*}{$\begin{array}{l}\text { Outside of } \\
\text { Africa }\end{array}$} & \multicolumn{6}{|c|}{ "Comovement with recipients' GDP } \\
\hline & \multicolumn{2}{|c|}{ ODA } & \multicolumn{2}{|c|}{ Mult } & \multicolumn{2}{|c|}{ Bilat } \\
\hline & $\mathrm{R}$ & $\mathrm{C}$ & $\mathrm{R}$ & $\mathrm{C}$ & $\mathrm{R}$ & $\mathrm{C}$ \\
\hline Bangladesh & + & + & + & + & + & + \\
\hline Bolivia & + & 0 & 0 & 0 & + & 0 \\
\hline Costa Rica & 0 & $+l$ & + & $+l$ & $+l$ & $+l$ \\
\hline Dominican Rep. & $+l$ & + & + & 0 & na & + \\
\hline Ecuador & - & 0 & 0 & 0 & - & - \\
\hline Guatemala & - & - & 0 & - & - & 0 \\
\hline Guyana & 0 & 0 & 0 & 0 & - & - \\
\hline Haiti & 0 & 0 & - & 0 & 0 & 0 \\
\hline Honduras & $+{ }_{l}$ & $+_{l}$ & 0 & $+_{l}$ & $+_{l}$ & 0 \\
\hline India & $+l$ & 0 & 0 & 0 & $++_{l}$ & $+_{l}$ \\
\hline Indonesia & - & - & 0 & 0 & - & - \\
\hline Jamaica & 0 & 0 & 0 & 0 & 0 & 0 \\
\hline Jordan & $+l$ & $+_{l}$ & $+l$ & $+_{l}$ & - & - \\
\hline Malaysia & 0 & 0 & 0 & $+{ }_{L}$ & 0 & 0 \\
\hline Mexico & $+{ }_{L}$ & + & na & 0 & na & + \\
\hline Nepal & + & $+_{L}$ & $+_{L}$ & $+{ }_{L}$ & + & $+_{L}$ \\
\hline Pakistan & 0 & 0 & $+{ }_{L}$ & $+l$ & + & 0 \\
\hline Panama & $+_{l}$ & $+_{l}$ & na & 0 & $+{ }_{l}$ & $+_{l}$ \\
\hline Paraguay & + & + & + & + & + & $+l$ \\
\hline Peru & 0 & 0 & $+_{L}$ & + & 0 & 0 \\
\hline Philippines & 0 & + & $+_{L}$ & + & 0 & + \\
\hline Salvador & - & 0 & 0 & 0 & 0 & 0 \\
\hline Sri Lanka & 0 & - & 0 & 0 & 0 & 0 \\
\hline Thailand & + & $+_{L}$ & + & + & + & $+{ }_{L}$ \\
\hline Uruguay & $+t_{l}$ & 0 & na & - & $+_{l}$ & 0 \\
\hline
\end{tabular}

Notes: For each recipient, the table reports whether aid series are procyclical, countercyclical or acyclical with its GDP. $R$ and $C$ stand, respectively, for net receipts and commitments. All other variables and abbreviations are defined in the note to Table 1. A " +" indicates procyclicality, subscripts "L" and "l" stand respectively for lag and lead, "-" indicates countercyclicality. Details of the underlying correlation$\mathrm{s}$ are reported in Table 5. A correlation is judged to be non-different from 0 if it lies in the interval $(-0.29,0.29)$. 
Table 5: Cyclical properties of aid from the recipient point of view - Panel I: Africa

\begin{tabular}{|c|c|c|c|c|c|c|}
\hline & \multirow[b]{2}{*}{ Var. } & \multicolumn{5}{|c|}{ Cross-correlation of GDP with: } \\
\hline & & $x(-2)$ & $x(-1)$ & $x$ & $x(+1)$ & $x(+2)$ \\
\hline \multirow[t]{4}{*}{ Benin } & GDP & 0.03 & 0.63 & 1.00 & 0.63 & 0.03 \\
\hline & ODA & 0.36 & 0.57 & 0.28 & 0.10 & -0.22 \\
\hline & Mult & 0.27 & 0.50 & 0.40 & 0.09 & -0.11 \\
\hline & Bilat & 0.32 & 0.46 & 0.12 & 0.08 & -0.23 \\
\hline \multirow[t]{4}{*}{ Botswana } & GDP & -0.00 & 0.49 & 1.00 & 0.49 & -0.00 \\
\hline & ODA & 0.30 & 0.45 & 0.49 & -0.10 & -0.27 \\
\hline & Mult & 0.17 & 0.05 & 0.16 & -0.30 & -0.13 \\
\hline & Bilat & 0.37 & 0.51 & 0.47 & 0.02 & -0.29 \\
\hline \multirow{4}{*}{$\begin{array}{l}\text { Burkina } \\
\text { Faso }\end{array}$} & GDP & 0.04 & 0.56 & 1.00 & 0.56 & 0.04 \\
\hline & ODA & -0.37 & 0.02 & 0.48 & 0.24 & -0.06 \\
\hline & Mult & -0.32 & 0.00 & 0.31 & 0.06 & -0.21 \\
\hline & Bilat & -0.40 & 0.10 & 0.65 & 0.45 & 0.13 \\
\hline \multirow[t]{4}{*}{ Burundi } & GDP & 0.29 & 0.66 & 1.00 & 0.66 & 0.29 \\
\hline & ODA & 0.03 & 0.05 & 0.31 & 0.56 & 0.37 \\
\hline & Mult & -0.18 & -0.22 & 0.23 & 0.48 & 0.60 \\
\hline & Bilat & 0.22 & 0.20 & 0.02 & -0.06 & -0.43 \\
\hline \multirow{4}{*}{$\begin{array}{l}\text { Came- } \\
\text { roon }\end{array}$} & GDP & 0.47 & 0.62 & 1.00 & 0.47 & 0.62 \\
\hline & ODA & 0.08 & 0.03 & 0.41 & 0.45 & 0.29 \\
\hline & Mult & 0.05 & 0.09 & 0.38 & 0.17 & 0.05 \\
\hline & Bilat & 0.10 & 0.01 & 0.38 & 0.52 & 0.39 \\
\hline \multirow{4}{*}{$\begin{array}{l}\text { Cape } \\
\text { Verde }\end{array}$} & GDP & -0.27 & 0.19 & 1.00 & 0.19 & -0.27 \\
\hline & ODA & -0.26 & 0.06 & 0.70 & -0.04 & -0.12 \\
\hline & Mult & -0.29 & 0.12 & 0.70 & -0.04 & -0.08 \\
\hline & Bilat & -0.19 & -0.07 & 0.34 & -0.08 & -0.24 \\
\hline \multirow{4}{*}{$\begin{array}{l}\text { Central } \\
\text { African } \\
\text { Rep. }\end{array}$} & GDP & -0.25 & 0.36 & 1.00 & 0.356 & -0.25 \\
\hline & ODA & -0.25 & 0.17 & 0.01 & -0.40 & 0.17 \\
\hline & Mult & -0.05 & 0.12 & -0.15 & -0.35 & 0.17 \\
\hline & Bilat & -0.35 & 0.09 & 0.15 & -0.24 & 0.17 \\
\hline \multirow[t]{4}{*}{ Chad } & GDP & 0.03 & 0.30 & 1.00 & 0.30 & 0.03 \\
\hline & ODA & -0.08 & 0.20 & 0.55 & 0.55 & 0.21 \\
\hline & Mult & -0.02 & 0.17 & 0.38 & 0.37 & 0.17 \\
\hline & Bilat & -0.13 & 0.19 & 0.61 & 0.61 & 0.18 \\
\hline \multirow[t]{4}{*}{ Congo } & GDP & 0.22 & 0.57 & 1.00 & 0.57 & 0.22 \\
\hline & ODA & -0.07 & -0.02 & 0.19 & 0.28 & 0.23 \\
\hline & Mult & 0.00 & 0.18 & 0.34 & 0.17 & 0.04 \\
\hline & Bilat & -0.18 & -0.21 & 0.07 & 0.20 & 0.40 \\
\hline \multirow{4}{*}{$\begin{array}{l}\text { Côte } \\
\text { d'Ivoire }\end{array}$} & GDP & 0.12 & 0.68 & 1.00 & 0.68 & 0.12 \\
\hline & ODA & 0.06 & 0.21 & 0.33 & 0.35 & 0.38 \\
\hline & Mult & -0.02 & 0.02 & 0.18 & 0.18 & 0.32 \\
\hline & Bilat & 0.05 & 0.23 & 0.23 & 0.25 & 0.20 \\
\hline
\end{tabular}

\begin{tabular}{|c|c|c|c|c|c|c|}
\hline & \multirow[b]{2}{*}{ Var. } & \multicolumn{5}{|c|}{ Cross-correlation of GDP with: } \\
\hline & & $x(-2)$ & $x(-1)$ & $x$ & $x(+1)$ & $x(+2)$ \\
\hline \multirow[t]{4}{*}{ Egypt } & GDP & -0.04 & 0.43 & 1.00 & 0.43 & -0.04 \\
\hline & ODA & 0.03 & -0.23 & -0.01 & -0.06 & -0.27 \\
\hline & Mult & 0.03 & -0.09 & -0.02 & -0.21 & -0.38 \\
\hline & Bilat & 0.24 & -0.06 & -0.17 & -0.19 & -0.39 \\
\hline \multirow[t]{4}{*}{ Gabon } & GDP & -0.18 & 0.48 & 1.00 & 0.48 & -0.18 \\
\hline & ODA & 0.05 & 0.13 & 0.08 & 0.07 & -0.39 \\
\hline & Mult & -0.03 & -0.27 & -0.74 & -0.37 & 0.18 \\
\hline & Bilat & -0.04 & 0.03 & 0.36 & 0.20 & -0.29 \\
\hline \multirow[t]{4}{*}{ Gambia } & GDP & 0.27 & 0.56 & 1.00 & 0.56 & 0.27 \\
\hline & ODA & 0.01 & 0.49 & 0.47 & 0.22 & 0.07 \\
\hline & Mult & 0.09 & 0.39 & 0.21 & 0.10 & 0.17 \\
\hline & Bilat & -0.14 & 0.18 & 0.34 & 0.05 & -0.24 \\
\hline \multirow[t]{4}{*}{ Ghana } & GDP & 0.18 & 0.66 & 1.00 & 0.66 & 0.18 \\
\hline & ODA & 0.51 & 0.68 & 0.69 & 0.25 & -0.04 \\
\hline & Mult & 0.41 & 0.58 & 0.56 & 0.23 & -0.11 \\
\hline & Bilat & 0.45 & 0.67 & 0.71 & 0.32 & 0.07 \\
\hline Guinea & GDP & -0.22 & 0.20 & 1.00 & 0.20 & -0.22 \\
\hline \multirow{3}{*}{ Bissau } & ODA & -0.60 & -0.56 & 0.42 & 0.06 & -0.24 \\
\hline & Mult & -0.54 & -0.36 & 0.44 & 0.20 & -0.25 \\
\hline & Bilat & -0.48 & -0.52 & 0.13 & -0.11 & -0.25 \\
\hline \multirow[t]{4}{*}{ Kenya } & GDP & -0.01 & 0.59 & 1.00 & 0.59 & -0.01 \\
\hline & ODA & -0.35 & 0.04 & 0.37 & 0.62 & 0.53 \\
\hline & Mult & -0.27 & -0.10 & 0.31 & 0.55 & 0.46 \\
\hline & Bilat & -0.34 & 0.19 & 0.46 & 0.61 & 0.49 \\
\hline \multirow[t]{4}{*}{ Lesotho } & GDP & 0.09 & 0.35 & 1.00 & 0.35 & 0.09 \\
\hline & ODA & -0.09 & 0.04 & 0.31 & 0.09 & 0.26 \\
\hline & Mult & 0.08 & 0.08 & 0.38 & -0.21 & -0.02 \\
\hline & Bilat & -0.15 & 0.04 & 0.17 & 0.30 & 0.35 \\
\hline \multirow[t]{4}{*}{ Liberia } & GDP & -0.27 & 0.52 & 1.00 & 0.52 & -0.27 \\
\hline & ODA & -0.24 & 0.05 & 0.22 & 0.04 & -0.08 \\
\hline & Mult & -0.33 & -0.21 & 0.12 & 0.42 & 0.54 \\
\hline & Bilat & -0.03 & 0.23 & 0.20 & -0.17 & -0.42 \\
\hline \multirow{4}{*}{$\begin{array}{l}\text { Mada- } \\
\text { gascar }\end{array}$} & GDP & -0.08 & 0.36 & 1.00 & 0.36 & -0.08 \\
\hline & ODA & -0.19 & -0.10 & 0.29 & 0.16 & -0.07 \\
\hline & Mult & -0.32 & -0.14 & 0.21 & 0.26 & -0.08 \\
\hline & Bilat & -0.01 & 0.01 & 0.35 & 0.11 & 0.05 \\
\hline \multirow[t]{4}{*}{ Malawi } & GDP & -0.03 & 0.28 & 1.00 & 0.28 & -0.03 \\
\hline & ODA & 0.27 & 0.26 & 0.17 & -0.17 & -0.47 \\
\hline & Mult & 0.21 & 0.39 & 0.49 & 0.00 & -0.25 \\
\hline & Bilat & 0.21 & -0.04 & -0.24 & -0.31 & -0.50 \\
\hline
\end{tabular}


Table 5, Panel I (continued)

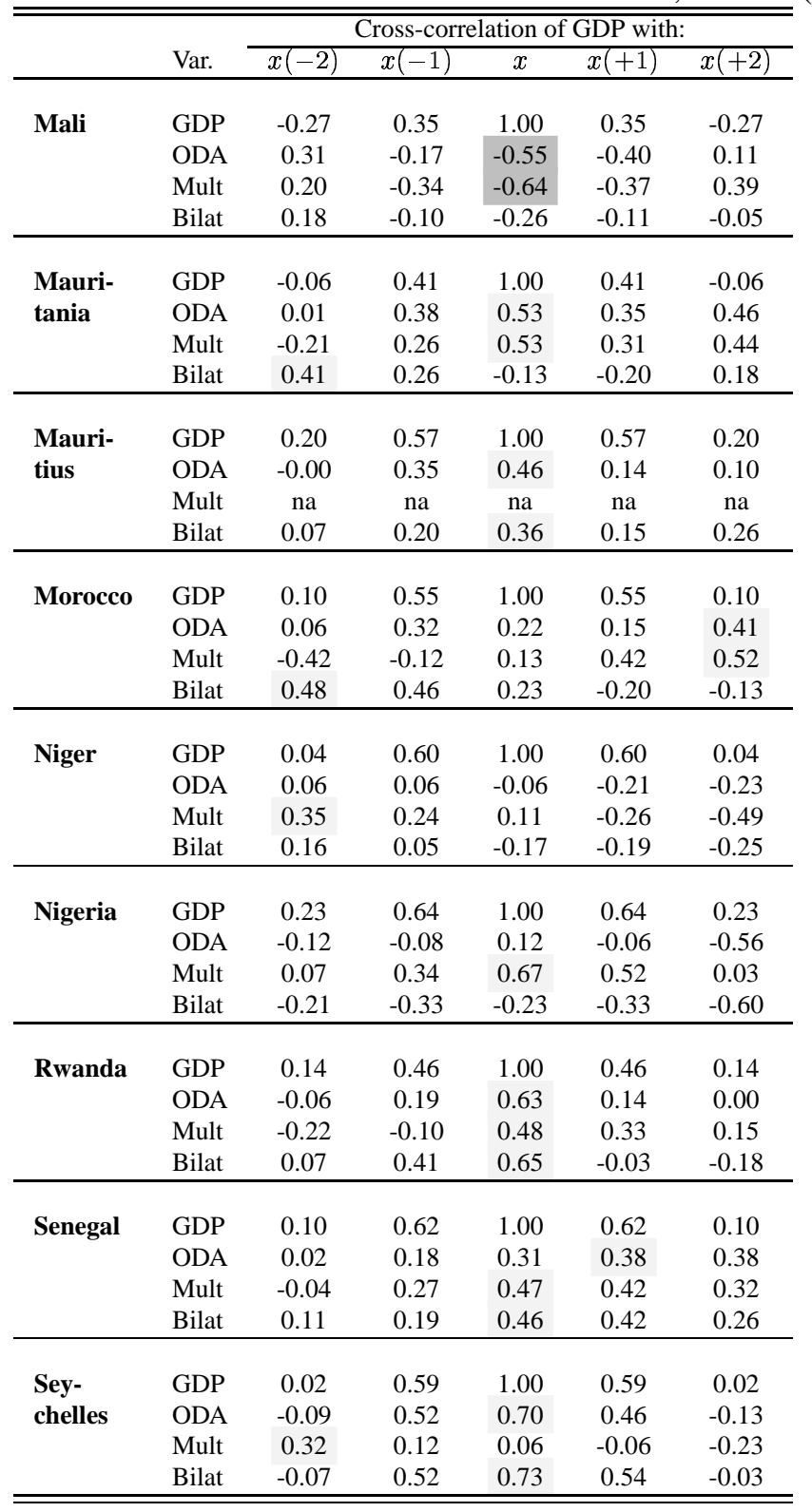

\begin{tabular}{|c|c|c|c|c|c|c|}
\hline & \multirow[b]{2}{*}{ Var. } & \multicolumn{5}{|c|}{ Cross-correlation of GDP with: } \\
\hline & & $x(-2)$ & $x(-1)$ & $x$ & $x(+1)$ & $x(+2)$ \\
\hline Sierra & GDP & 0.03 & 0.50 & 1.00 & 0.50 & 0.03 \\
\hline \multirow{3}{*}{ Leone } & ODA & 0.25 & 0.51 & 0.82 & 0.26 & -0.21 \\
\hline & Mult & 0.38 & 0.59 & 0.64 & 0.00 & -0.20 \\
\hline & Bilat & 0.08 & 0.42 & 0.79 & 0.36 & -0.19 \\
\hline \multirow[t]{4}{*}{ Somalia } & GDP & -0.38 & 0.40 & 1.00 & 0.40 & -0.38 \\
\hline & ODA & -0.15 & 0.20 & 0.49 & 0.12 & 0.08 \\
\hline & Mult & 0.05 & 0.36 & 0.29 & -0.18 & -0.24 \\
\hline & Bilat & -0.27 & 0.04 & 0.63 & 0.29 & 0.09 \\
\hline \multirow[t]{4}{*}{ Sudan } & GDP & 0.19 & 0.54 & 1.00 & 0.54 & 0.19 \\
\hline & ODA & 0.49 & 0.31 & -0.12 & -0.11 & -0.46 \\
\hline & Mult & 0.17 & 0.08 & -0.18 & -0.18 & -0.39 \\
\hline & Bilat & na & na & na & na & na \\
\hline \multirow{4}{*}{ Swaziland } & GDP & -0.07 & 0.24 & 1.00 & 0.24 & -0.07 \\
\hline & ODA & 0.02 & -0.04 & 0.03 & -0.48 & 0.08 \\
\hline & Mult & -0.46 & 0.02 & -0.02 & -0.38 & -0.08 \\
\hline & Bilat & 0.10 & -0.06 & 0.06 & -0.48 & 0.06 \\
\hline \multirow[t]{4}{*}{ Tanzania } & GDP & 0.22 & 0.61 & 1.00 & 0.61 & 0.22 \\
\hline & ODA & 0.04 & -0.35 & -0.63 & -0.49 & -0.23 \\
\hline & Mult & 0.35 & 0.12 & -0.22 & -0.35 & -0.39 \\
\hline & Bilat & -0.21 & -0.58 & -0.75 & -0.46 & -0.07 \\
\hline \multirow[t]{4}{*}{ Togo } & GDP & -0.24 & 0.21 & 1.00 & 0.21 & -0.24 \\
\hline & ODA & 0.10 & 0.07 & 0.55 & 0.09 & -0.14 \\
\hline & Mult & 0.22 & 0.09 & 0.33 & -0.16 & -0.09 \\
\hline & Bilat & -0.04 & 0.05 & 0.69 & 0.38 & -0.13 \\
\hline \multirow[t]{4}{*}{ Tunisia } & GDP & 0.02 & 0.19 & 1.00 & 0.19 & 0.02 \\
\hline & ODA & 0.13 & 0.09 & 0.03 & -0.30 & -0.41 \\
\hline & Mult & 0.24 & 0.08 & -0.24 & -0.41 & -0.12 \\
\hline & Bilat & -0.08 & 0.11 & 0.16 & -0.19 & -0.35 \\
\hline \multirow[t]{4}{*}{ Zaire } & GDP & -0.35 & 0.16 & 1.00 & 0.16 & -0.35 \\
\hline & ODA & -0.08 & 0.13 & 0.66 & 0.40 & -0.00 \\
\hline & Mult & 0.24 & 0.23 & 0.66 & 0.06 & -0.28 \\
\hline & Bilat & -0.25 & 0.07 & 0.61 & 0.50 & 0.13 \\
\hline \multirow[t]{4}{*}{ Zambia } & GDP & -0.12 & 0.36 & 1.00 & 0.36 & -0.12 \\
\hline & ODA & 0.38 & 0.52 & 0.27 & -0.14 & -0.43 \\
\hline & Mult & 0.42 & 0.36 & -0.18 & -0.38 & -0.49 \\
\hline & Bilat & 0.37 & 0.55 & 0.42 & -0.01 & -0.30 \\
\hline
\end{tabular}


Table 5, Panel II: Non-African recipients

\begin{tabular}{|c|c|c|c|c|c|c|c|c|c|c|c|c|c|}
\hline & \multirow[b]{2}{*}{ Var. } & \multicolumn{5}{|c|}{ Cross-correlation of GDP with: } & & \multirow[b]{2}{*}{ Var. } & \multicolumn{5}{|c|}{ Cross-correlation of GDP with: } \\
\hline & & $x(-2)$ & $x(-1)$ & $x$ & $x(+1)$ & $x(+2)$ & & & $x(-2)$ & $x(-1)$ & $x$ & $x(+1)$ & $x(+2)$ \\
\hline \multirow[t]{4}{*}{ Bangladesh } & GDP & -0.47 & 0.27 & 1.00 & 0.27 & -0.47 & \multirow{4}{*}{$\begin{array}{l}\text { Indo- } \\
\text { nesia }\end{array}$} & GDP & -0.01 & 0.52 & 1.00 & 0.52 & -0.01 \\
\hline & ODA & -0.25 & 0.27 & 0.76 & 0.05 & -0.09 & & ODA & -0.18 & -0.49 & -0.42 & -0.27 & -0.21 \\
\hline & Mult & -0.20 & 0.37 & 0.74 & 0.31 & 0.04 & & Mult & -0.13 & -0.13 & -0.19 & -0.14 & -0.27 \\
\hline & Bilat & -0.17 & 0.20 & 0.75 & 0.01 & -0.33 & & Bilat & -0.15 & -0.48 & -0.42 & -0.26 & -0.15 \\
\hline \multirow[t]{4}{*}{ Bolivia } & GDP & 0.24 & 0.59 & 1.00 & 0.59 & 0.24 & \multirow[t]{4}{*}{ Jamaica } & GDP & 0.24 & 0.64 & 1.00 & 0.64 & 0.24 \\
\hline & ODA & 0.29 & 0.39 & 0.49 & 0.10 & -0.06 & & ODA & -0.36 & -0.31 & -0.01 & 0.27 & 0.23 \\
\hline & Mult & 0.14 & 0.06 & -0.01 & 0.01 & -0.22 & & Mult & -0.19 & -0.03 & 0.14 & 0.17 & -0.02 \\
\hline & Bilat & 0.27 & 0.40 & 0.53 & 0.10 & 0.03 & & Bilat & -0.32 & -0.28 & -0.02 & 0.25 & 0.17 \\
\hline \multirow{4}{*}{$\begin{array}{l}\text { Costa } \\
\text { Rica }\end{array}$} & GDP & 0.00 & 0.59 & 1.00 & 0.59 & 0.00 & \multirow[t]{4}{*}{ Jordan } & GDP & 0.45 & 0.72 & 1.00 & 0.72 & 0.45 \\
\hline & ODA & 0.17 & 0.29 & 0.17 & -0.31 & -0.58 & & ODA & 0.71 & 0.30 & 0.01 & -0.41 & -0.38 \\
\hline & Mult & -0.19 & 0.03 & 0.31 & 0.14 & -0.07 & & Mult & 0.60 & 0.54 & 0.07 & -0.29 & -0.64 \\
\hline & Bilat & 0.31 & 0.32 & 0.01 & -0.43 & -0.63 & & Bilat & 0.10 & -0.09 & -0.49 & -0.74 & -0.55 \\
\hline \multirow{4}{*}{$\begin{array}{l}\text { Dominican } \\
\text { Republic }\end{array}$} & GDP & -0.25 & 0.1755 & 1.00 & 0.18 & -0.25 & \multirow{4}{*}{$\begin{array}{l}\text { Malay- } \\
\text { sia }\end{array}$} & GDP & -0.29 & 0.31 & 1.00 & 0.31 & -0.29 \\
\hline & ODA & 0.14 & 0.33 & 0.13 & 0.02 & 0.22 & & ODA & -0.16 & -0.10 & 0.02 & 0.10 & 0.15 \\
\hline & Mult & 0.15 & 0.11 & 0.33 & 0.25 & -0.02 & & Mult & -0.06 & 0.04 & 0.18 & 0.19 & 0.02 \\
\hline & Bilat & na & na & na & na & na & & Bilat & -0.18 & -0.14 & -0.03 & 0.08 & 0.15 \\
\hline \multirow[t]{4}{*}{ Ecuador } & GDP & 0.50 & 0.81 & 1.00 & 0.81 & 0.50 & \multirow[t]{4}{*}{ Mexico } & GDP & 0.07 & 0.55 & 1.00 & 0.55 & 0.07 \\
\hline & ODA & -0.33 & -0.42 & -0.44 & -0.47 & -0.33 & & ODA & -0.36 & -0.33 & 0.07 & 0.58 & 0.32 \\
\hline & Mult & -0.25 & -0.14 & -0.09 & -0.22 & -0.21 & & Mult & na & na & na & na & na \\
\hline & Bilat & -0.30 & -0.50 & -0.51 & -0.45 & -0.28 & & Bilat & na & na & na & na & na \\
\hline \multirow[t]{4}{*}{ Guatemala } & GDP & 0.11 & 0.57 & 1.00 & 0.57 & 0.11 & \multirow[t]{4}{*}{ Nepal } & GDP & -0.31 & 0.19 & 1.00 & 0.19 & -0.31 \\
\hline & ODA & -0.12 & -0.24 & -0.41 & -0.45 & -0.28 & & ODA & -0.22 & -0.15 & 0.57 & 0.45 & -0.14 \\
\hline & Mult & 0.19 & 0.18 & 0.09 & -0.10 & -0.16 & & Mult & -0.05 & -0.10 & 0.38 & 0.51 & 0.02 \\
\hline & Bilat & -0.22 & -0.39 & -0.54 & -0.54 & -0.29 & & Bilat & -0.23 & -0.20 & 0.61 & 0.40 & -0.24 \\
\hline \multirow[t]{4}{*}{ Guyana } & GDP & 0.19 & 0.37 & 1.00 & 0.37 & 0.19 & \multirow{4}{*}{$\begin{array}{l}\text { Pana- } \\
\text { ma }\end{array}$} & GDP & 0.11 & 0.64 & 1.00 & 0.64 & 0.11 \\
\hline & ODA & -0.15 & -0.41 & -0.20 & -0.30 & -0.44 & & ODA & 0.47 & 0.59 & 0.38 & -0.07 & -0.46 \\
\hline & Mult & 0.04 & -0.20 & -0.13 & -0.36 & -0.43 & & Mult & na & na & na & na & na \\
\hline & Bilat & -0.44 & -0.65 & -0.33 & -0.14 & -0.15 & & Bilat & 0.42 & 0.46 & 0.28 & -0.12 & -0.48 \\
\hline \multirow[t]{4}{*}{ Haiti } & GDP & -0.23 & 0.18 & 1.00 & 0.18 & -0.23 & \multirow{4}{*}{$\begin{array}{l}\text { Paki- } \\
\text { stan }\end{array}$} & GDP & 0.03 & 0.61 & 1.00 & 0.61 & 0.03 \\
\hline & ODA & 0.16 & 0.06 & -0.06 & -0.14 & 0.04 & & ODA & 0.12 & 0.23 & 0.21 & -0.05 & -0.07 \\
\hline & Mult & 0.13 & 0.02 & -0.31 & -0.31 & -0.01 & & Mult & -0.01 & 0.08 & 0.20 & 0.05 & 0.37 \\
\hline & Bilat & 0.13 & 0.02 & 0.07 & -0.05 & 0.06 & & Bilat & -0.07 & 0.27 & 0.37 & 0.34 & -0.00 \\
\hline \multirow[t]{4}{*}{ Honduras } & GDP & -0.25 & 0.50 & 1.00 & 0.50 & -0.25 & Para- & GDP & 0.18 & 0.61 & 1.00 & 0.61 & 0.18 \\
\hline & ODA & 0.47 & 0.37 & -0.03 & -0.19 & -0.11 & guay & ODA & -0.12 & 0.03 & 0.56 & 0.22 & -0.05 \\
\hline & Mult & 0.20 & 0.10 & -0.09 & -0.22 & -0.31 & & Mult & -0.53 & -0.03 & 0.43 & 0.41 & 0.21 \\
\hline & Bilat & 0.44 & 0.30 & -0.09 & -0.19 & 0.11 & & Bilat & 0.05 & 0.13 & 0.59 & 0.12 & -0.16 \\
\hline India & GDP & 0.01 & 0.40 & 1.00 & 0.40 & 0.01 & Peru & GDP & -0.33 & 0.24 & 1.00 & 0.24 & -0.33 \\
\hline & ODA & 0.53 & 0.09 & -0.05 & -0.25 & 0.04 & & ODA & 0.20 & 0.28 & 0.19 & -0.15 & -0.39 \\
\hline & Mult & 0.16 & 0.01 & 0.03 & -0.20 & 0.10 & & Mult & -0.02 & -0.06 & 0.13 & 0.18 & 0.38 \\
\hline & Bilat & 0.42 & 0.03 & 0.01 & -0.05 & 0.07 & & Bilat & 0.22 & 0.28 & 0.13 & -0.20 & -0.46 \\
\hline
\end{tabular}


Table 5, Panel II (continued)

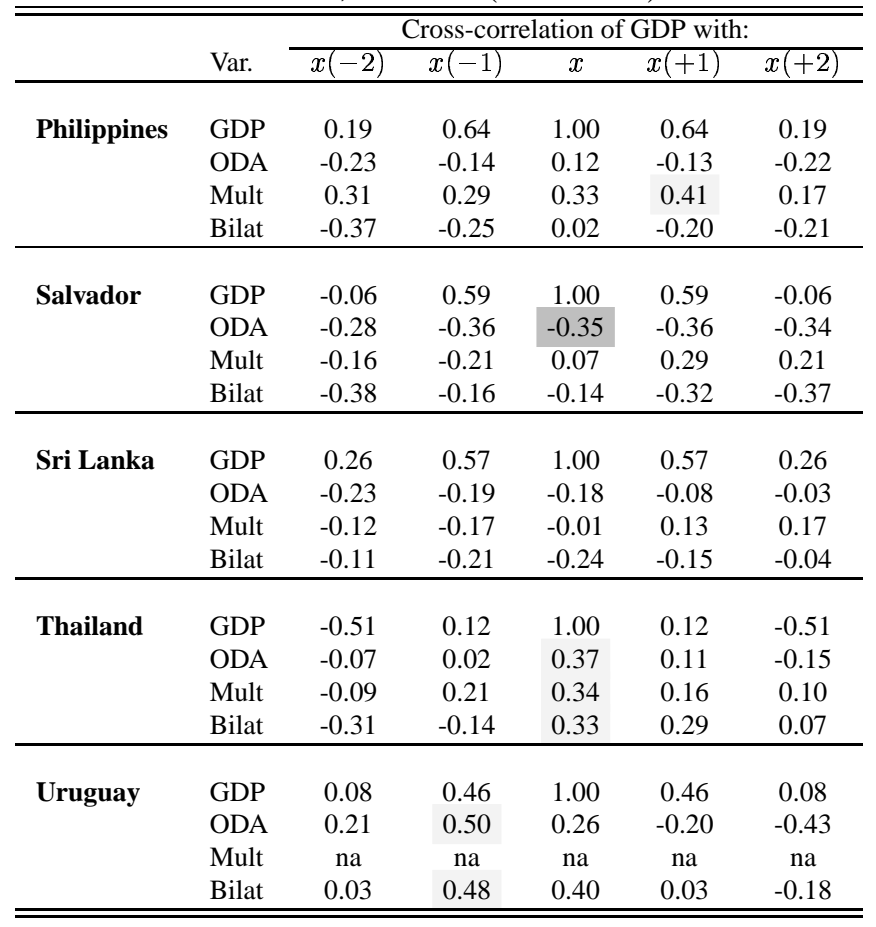

Notes: Entries are correlations of the cyclical components of the HodrickPrescott filtered logarithms of the series. The central column shows contemporaneous correlations. Columns to the right (left) are correlations with the series shifted backward (forward) by one to two years. All variables are defined in the notes to Table 1 . A correlation is judged to be non-different from 0 if it lies in the interval $(-0.29,0.29)$. 
Table 6: Importance of foreign aid to donors (1969-1995)

\begin{tabular}{|c|c|c|c|c|c|c|}
\hline \multirow[b]{3}{*}{ Donor country } & \multicolumn{6}{|c|}{ Mean ratio of ODA to donor's GDP (\%) } \\
\hline & \multicolumn{3}{|c|}{ Net Disbursements } & \multicolumn{3}{|c|}{ Commitments } \\
\hline & Total & Africa & Others & Total & Africa & Others \\
\hline Australia & 0.32 & 0.01 & 0.08 & 0.34 & 0.01 & 0.08 \\
\hline Austria & 0.16 & 0.03 & 0.03 & 0.22 & 0.06 & 0.04 \\
\hline Belgium & 0.32 & 0.21 & 0.04 & 0.34 & 0.20 & 0.04 \\
\hline Canada & 0.29 & 0.07 & 0.10 & 0.36 & 0.10 & 0.13 \\
\hline Denmark & 0.39 & 0.15 & 0.09 & 0.45 & 0.17 & 0.11 \\
\hline Finland & 0.21 & 0.09 & 0.03 & 0.27 & 0.11 & 0.04 \\
\hline France & 0.40 & 0.18 & 0.03 & 0.47 & 0.22 & 0.04 \\
\hline Germany & 0.28 & 0.09 & 0.08 & 0.40 & 0.12 & 0.12 \\
\hline Ireland & 0.06 & 0.03 & 0.00 & 0.05 & 0.03 & 0.00 \\
\hline Italy & 0.12 & 0.04 & 0.02 & 0.16 & 0.06 & 0.02 \\
\hline Japan & 0.19 & 0.02 & 0.11 & 0.29 & 0.03 & 0.17 \\
\hline Netherlands & 0.58 & 0.14 & 0.19 & 0.68 & 0.15 & 0.23 \\
\hline New Zealand & 0.21 & 0.00 & 0.04 & 0.21 & 0.00 & 0.04 \\
\hline Norway & 0.44 & 0.16 & 0.11 & 0.44 & 0.17 & 0.09 \\
\hline Sweden & 0.51 & 0.13 & 0.10 & 0.55 & 0.14 & 0.10 \\
\hline Switzerland & 0.18 & 0.05 & 0.06 & 0.20 & 0.06 & 0.06 \\
\hline United Kingdom & 0.22 & 0.06 & 0.08 & 0.28 & 0.07 & 0.11 \\
\hline United States & 0.17 & 0.04 & 0.05 & 0.22 & 0.05 & 0.06 \\
\hline Average & 0.28 & 0.08 & 0.07 & 0.33 & 0.10 & 0.08 \\
\hline Median & 0.25 & 0.07 & 0.07 & 0.32 & 0.09 & 0.07 \\
\hline Standard-deviation & 0.14 & 0.06 & 0.05 & 0.15 & 0.07 & 0.06 \\
\hline
\end{tabular}

Notes: GDP is the gross domestic product per capita in constant local currency $(1990=100)$. $O D A$ stands for official development assistance per capita in constant local currency; current US\$ amounts are converted into constant local currency using current exchange rates and local GDP deflators. All data are from the OECD. Total stands for aid flows to all aid recipients worldwide, whether in our sample or not; Africa, for aid flows to the 38 African countries in our recipient sample; Others, for aid flows to the 25 non-African recipients in the sample. Ratios are averaged over the period 1969-95, except for Austria (1971-95), Belgium and Netherlands (1970-95), Germany (West Germany, 1969-90), Ireland (1974-93) and New Zealand (1972-95). 
Table 7: Cyclical properties of foreign aid from donors' perspective

\begin{tabular}{|c|c|c|c|c|c|c|}
\hline \multirow[b]{3}{*}{ Donor country } & \multicolumn{6}{|c|}{ Comovements with donors' GDP } \\
\hline & \multicolumn{3}{|c|}{ Net ODA Disbursements } & \multicolumn{3}{|c|}{ ODA Commitments } \\
\hline & Total & Africa & Others & Total & Africa & Others \\
\hline Australia & 0 & - & 0 & $+l$ & 0 & $+l$ \\
\hline Austria & $+{ }_{L}$ & 0 & na & $+_{L}$ & $+_{L}$ & $+_{L}$ \\
\hline Belgium & $+{ }_{L}$ & 0 & $+_{L}$ & + & $+{ }_{L}$ & $+{ }_{L}$ \\
\hline Canada & $+l$ & 0 & $+l$ & $+l$ & $+l$ & $+l$ \\
\hline Denmark & $+{ }_{L}$ & $+{ }_{L}$ & $+_{L}$ & 0 & + & 0 \\
\hline Finland & $+_{L}$ & $+_{L}$ & $+_{L}$ & $+_{L}$ & + & + \\
\hline France & - & 0 & 0 & 0 & 0 & 0 \\
\hline Germany & 0 & 0 & - & $+_{L}$ & $+{ }_{L}$ & $+{ }_{L}$ \\
\hline Ireland & $+{ }_{L}$ & $+{ }_{L}$ & - & $+_{L}$ & $+{ }_{L}$ & - \\
\hline Italy & - & na & na & - & - & - \\
\hline Japan & $+_{L}$ & 0 & + & $+_{L}$ & $+_{L}$ & + \\
\hline Netherlands & $+{ }_{L}$ & + & + & + & $+_{L}$ & + \\
\hline New Zealand & $+{ }_{L}$ & 0 & 0 & na & na & na \\
\hline Norway & $+l$ & $+{ }_{l}$ & 0 & $+l$ & $+l$ & $+{ }_{l}$ \\
\hline Sweden & $+{ }_{L}$ & $+{ }_{L}$ & 0 & 0 & 0 & 0 \\
\hline Switzerland & $+_{L}$ & 0 & - & 0 & 0 & - \\
\hline United Kingdom & $+{ }_{L}$ & $+{ }_{L}$ & 0 & + & + & $+_{L}$ \\
\hline United States & 0 & 0 & 0 & 0 & 0 & 0 \\
\hline
\end{tabular}

Notes: For each donor, the table reports whether that donor's aid series are procyclical, countercyclical or acyclical with its GDP. Variables and abbreviations are defined in the note to Table 6. A " +" indicates procyclicality, subscripts " $L$ " and "l" stand respectively for lag and lead, "-" indicates countercyclicality. The underlying correlations are considered non-different from zero if they lie in the interval $(-0.29,0.29)$. 
Figure 1: Contemporaneous correlations between aid and recipient GDP
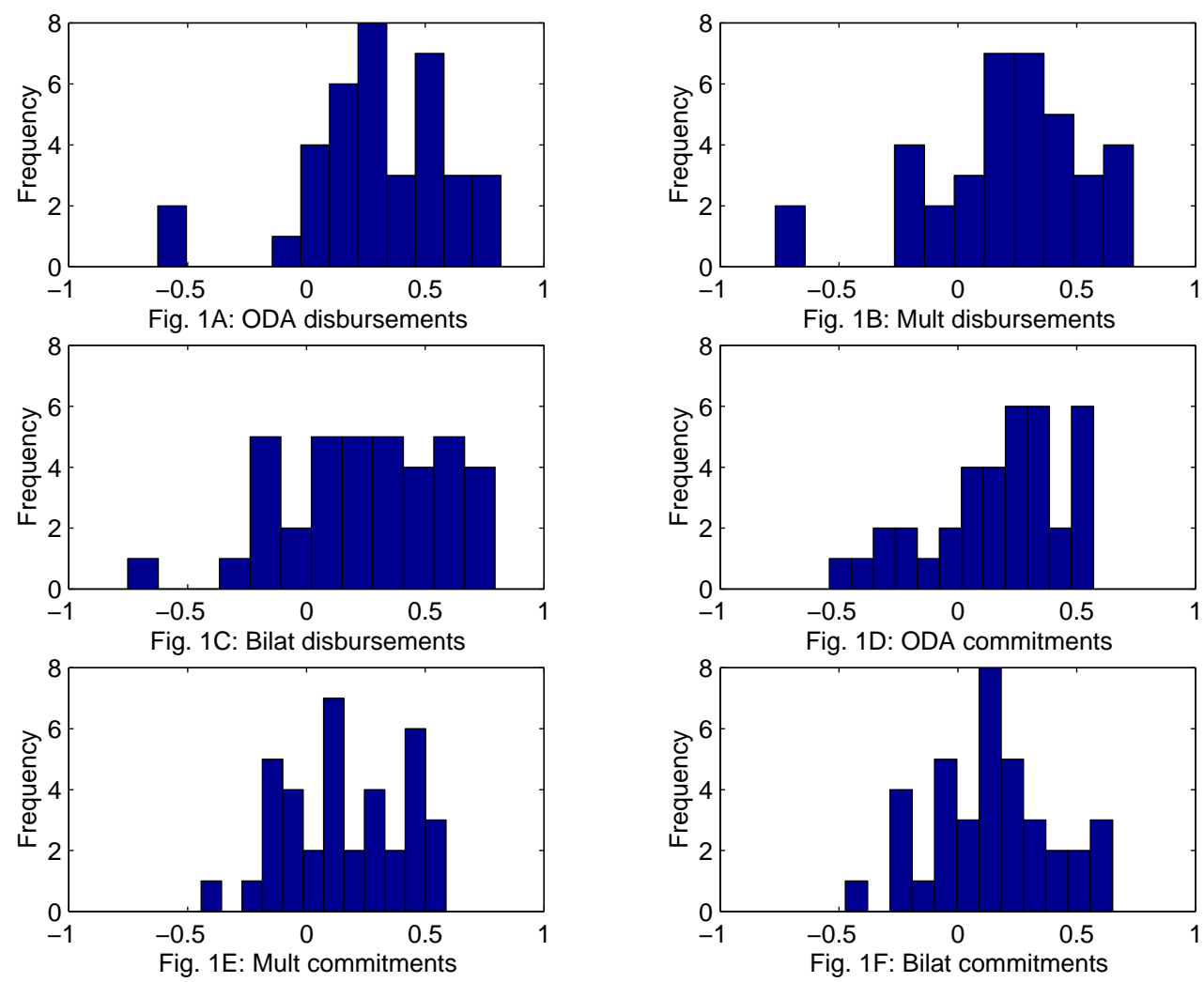

Note: Figure 1 shows the distribution of the contemporaneous correlations between African recipients' GDP and total ODA disbursements (Fig. 1A), ODA disbursements from multilateral (Fig. 1B) and bilateral sources (Fig. 1C), and commitments (Fig. 1D-F). 
Figure 2: Aid-output correlations vs. income, volatility and aid dependency
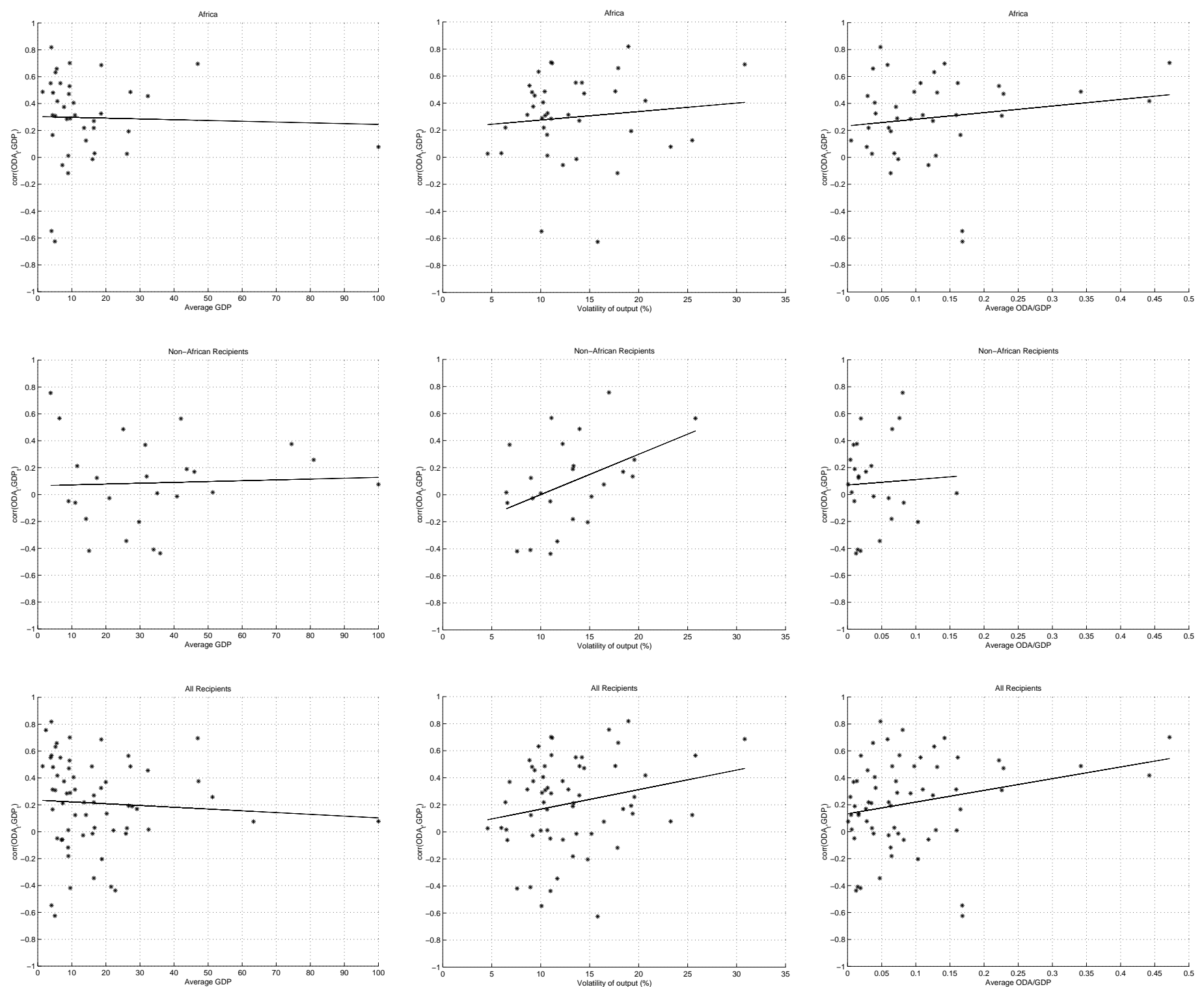

Note: This figure plots the contemporaneous correlation between the cyclical components of the H-P filtered logarithms of GDP and ODA against the average level of per-capita output (first column), the volatility of output (second column) or the average ODA/GDP ratio (third column), for African (first row), non-African (second row) and all 63 sample recipients. In each case, the solid line is the OLS-fitted line. Average GDP numbers in the first column have been normalized so that the highest is 100. 
Figure 3: Part A - Selected countries, detrended series
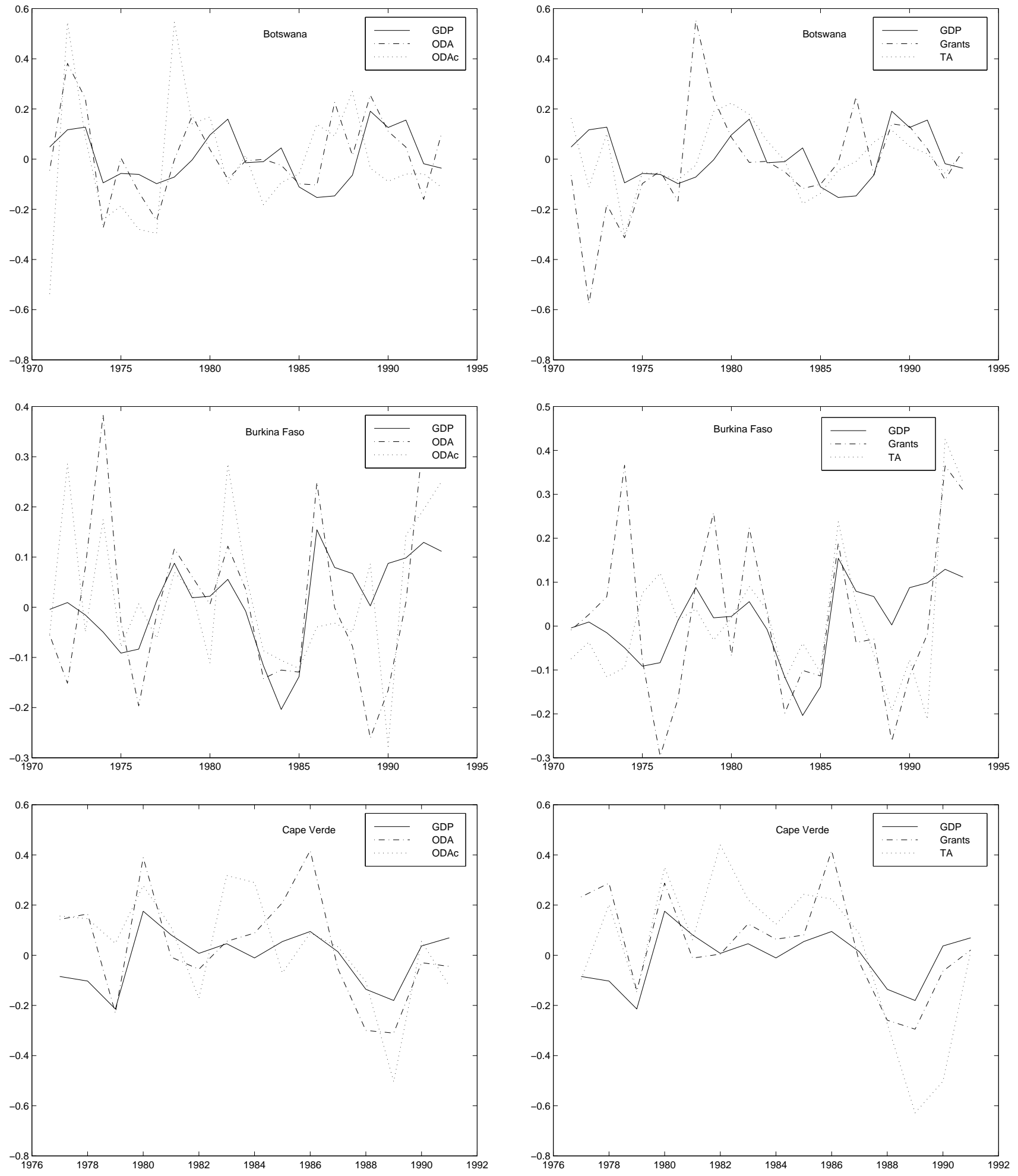

Note: Each figure plots the cyclical components of the HP-filtered logarithms of the per-capita series (GDP: growth domestic product; ODA: net disbursements of official development assistance; ODAc: ODA commitments; Grants: the grant component of ODA; TA: the value of technical assistance). The first and last two years of observations are not displayed as they have been dropped when we computed correlations and standard deviations. 
Figure 3: Part B
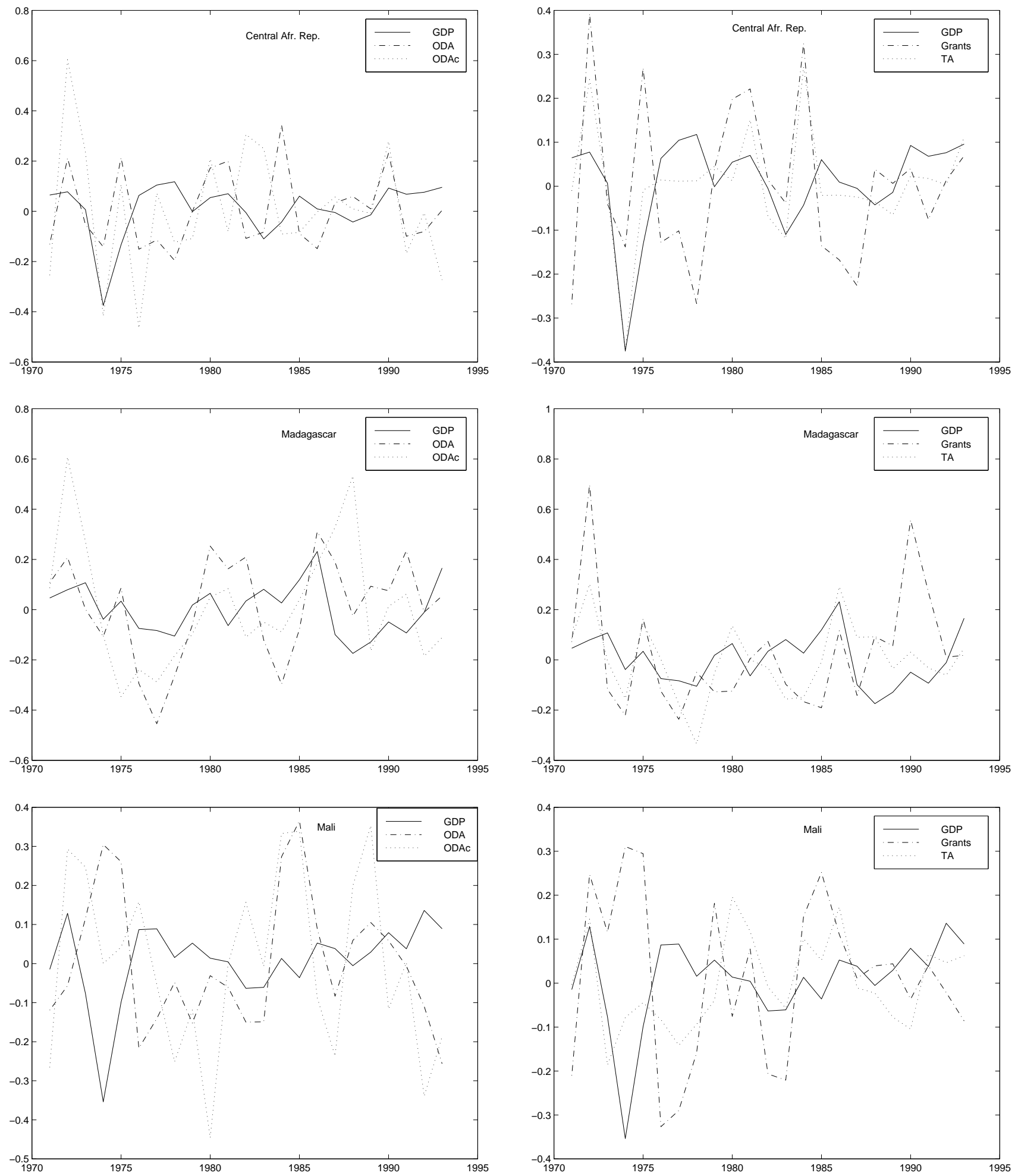

Note: Each figure plots the cyclical components of the HP-filtered logarithms of the per-capita series (GDP: growth domestic product; ODA: net disbursements of official development assistance; ODAc: ODA commitments; Grants: the grant component of ODA; TA: the value of technical assistance). The first and last two years of observations are not displayed as they have been dropped when we computed correlations and standard deviations. 
Figure 3: Part C
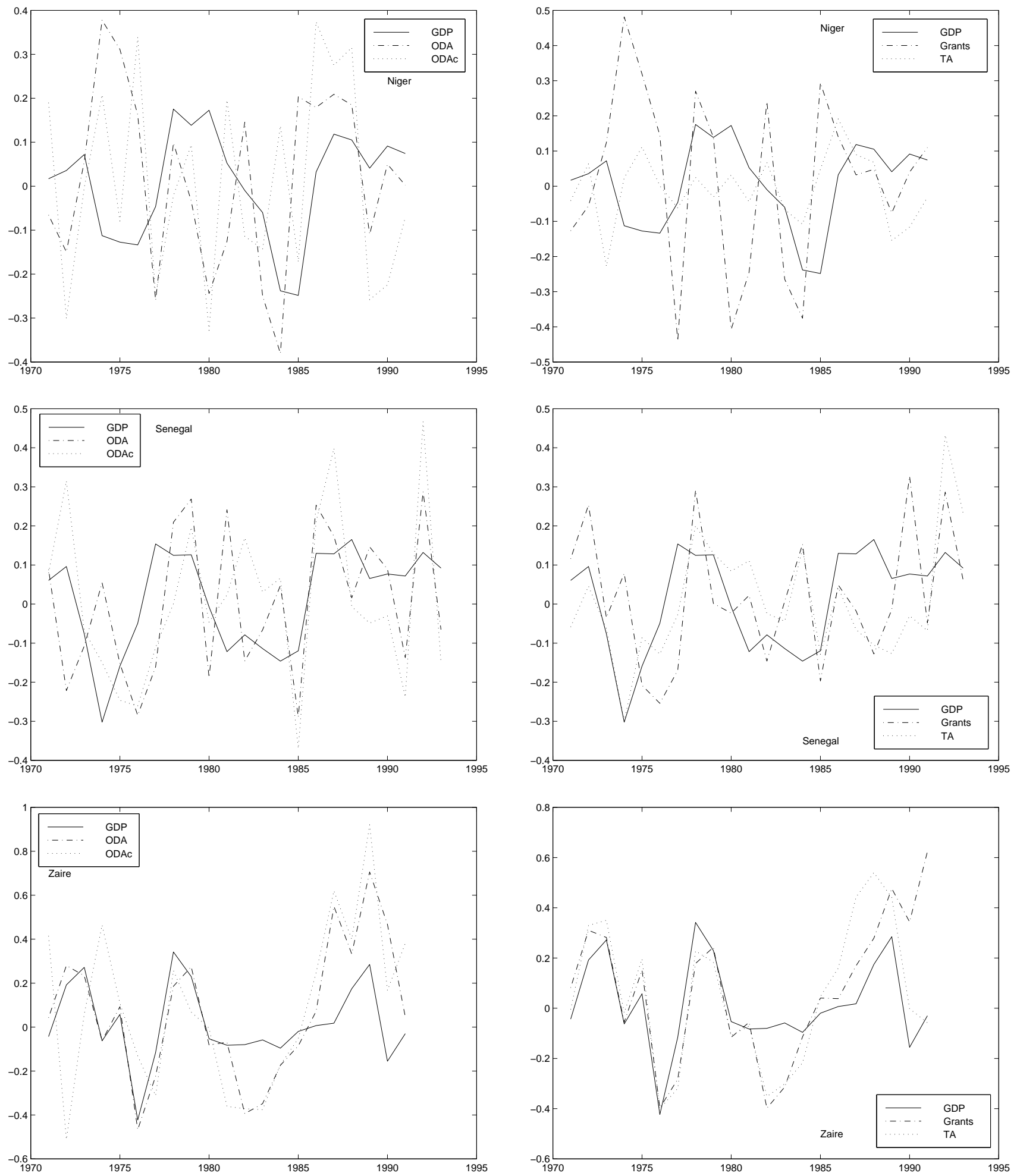

Note: Each figure plots the cyclical components of the HP-filtered logarithms of the per-capita series (GDP: growth domestic product; ODA: net disbursements of official development assistance; ODAc: ODA commitments; Grants: the grant component of ODA; TA: the value of technical assistance). The first and last two years of observations are not displayed as they have been dropped when we computed correlations and standard deviations. 